\title{
'VICTIMS' OF THE STATUS QUO: CANADA'S ONGOING MARGINALIZATION OF SEX WORKERS
}

\section{KENDRA STANYON}

Master of Arts in Communication \& Culture Ryerson University 


\begin{abstract}
The conflict between a sex worker's natural right to dignity, and the scope of control she can exert over her own body - her rightful property - plays a central part in much of the research and debate surrounding the commercialization of sex, and there is little consensus as to which natural right is of greater fundamental importance. This conflict over the morality and legal rights of sex workers is plainly evident in Canada's own treatment of the issue; spanning a period of over twenty-five years, the research and reports on prostitution commissioned by the federal government constitute several thousand pages of empirical evidence documenting the harm caused by the criminalization of prostitution, yet no changes have been made to the country's Criminal Code provisions since 1986. Throughout these government reports and the testimony of dozens of participants in the 2005 hearings held by the country's Subcommittee on Solicitation Laws, the same conflict of language and ideology is repeated; regardless of the time and location, conversations about prostitution within Canada follow an almost predictable pattern of spinning wheels and little progress.

In light of the new opportunity to effect change in Canada's approach to prostitution law, this paper examines the signs and significations evinced in the language of Canada's present laws, and traces the legislative history of sex work in the country as well as the cyclical nature of the observations and conclusions drawn by the many federally-appointed committees charged with addressing the topic. Select witness testimony from hearings conducted by the most recent committee to address the state of prostitution, the Subcommittee on Solicitation Laws, is also reproduced and analyzed. Using the opposing perspectives of victim and rights discourse as a loose framework, particular analytical focus is placed on the language used and ideological beliefs expressed within both the formal reports and testimony. Finally, the core conflicts revealed in Canada's hearings and formal reports on prostitution are placed within a larger body of theory on human agency and the physical body for the purpose of emphasizing the unequivocal necessity of respecting sex workers' autonomy, first and foremost, in any future determination of sex work's place within the social and legal fabric of the country.
\end{abstract}


Whether or not it is, indeed, the 'oldest profession' - farming may be a more likely candidate - prostitution exists within a lengthy history of discord between those who would support it and those who condemn it in all forms. With almost as many variations in legal regimes as there are countries, prostitution has also featured prominently in countless political debates. Within Canada, prostitution has actually remained legal since politicians and lawyers first formally considered the topic in 1892 , despite numerous sex work-related prohibitions found in the country's Criminal Code. Prevented from soliciting customers in public and performing commercial sex acts in public or private, sex workers are often forced to operate on the periphery of communities, risking their health and physical safety as a result of their impaired ability to dictate the parameters of their interactions with clients.

With a new constitutional challenge addressing the validity of prostitution-related offenses in the Criminal Code, the federal government once again faces an opportunity to acknowledge the increased danger the country's ineffectual and contradictory laws pose to sex workers. The longevity of the debate over prostitution's place in Canadian society indicates that sex work will remain a visible social issue for the foreseeable future, and the empirical research conducted by both the government and independent organizations over the past two decades is clear; only a collective effort towards the decisive implementation of a hybrid approach of decriminalization and regulation appears likely to effectively address the rights and needs of both sex workers and the members of communities adversely affected by street prostitution. Nevertheless, as the current challenge relies primarily on research and argumentation already presented to the government in earlier reports and recommendations, there remains the very real possibility that the factors influencing the Canadian government's historic refusal to significantly alter the country's laws will once again prevent any real beneficial change. 
Given how little progress has been made over twenty-five years in addressing the problems of sex work within Canada or even reaching a consensus on the what the 'reality' of prostitution entails, there is a pressing need for lawmakers in the country to identify what underlying conflicts are stalling potential progress. Within much of the research surrounding the commercialization of sex', it is the conflict between a sex worker's natural right to dignity, and the scope of control she can exert over her own body - her rightful property - which plays a central part, and there is little consensus as to which natural right is of greater fundamental importance. Two distinct, opposing schools of thought on the nature of human agency in prostitution have emerged in recent years; rooted in the belief that sex and the physical body cannot be separated from sexuality and the self, 'victim discourse' views prostitution, regardless of consent, as "the institutional, economic, and sexual model for women's oppression", while 'rights discourse' advocates an understanding of sex work as work, that can be consented to and performed by women without a loss of identity or morality. ${ }^{3}$ Though the ideological reasoning of both discourses appears irreconcilable, it is the language used by proponents of victim discourse to define and manipulate the debate on prostitution that truly bars those on either side of the spectrum from holding a constructive conversation and identifying common ground. For those who would abolish prostitution, sex workers are all too often imagined as helpless outcasts without autonomy or even a personal identity and place within society. Though this perspective is purportedly rooted in the desire to 'save' these individuals, the characterization of prostitutes as removed from society and unable to take care of themselves has the convenient effect of

\footnotetext{
'Kathleen Barry, The prostitution of sexuality (New York: New York University Press, 1995); Wendy Chapkis, Live sex acts: Women performing erotic labour (London: Cassell, 1997); Sheila Jeffreys, The idea of prostitution (Melbourne: Spinifex, 1997); Pateman.

${ }^{2}$ Barry 24.

${ }^{3}$ Julia O'Connell Davidson, Prostitution, Power and Freedom (Ann Arbor: University of Michigan Press, 1998).
} 
essentially removing sex workers from the debate entirely - dismissing their experiential knowledge and silencing their voices.

In light of the new opportunity to effect change in Canada's approach to prostitution law, this paper examines the signs and significations evinced in the language of Canada's present laws, and traces the legislative history of sex work in the country as well as the cyclical nature of the observations and conclusions drawn by the many federally-appointed committees charged with addressing the topic. Select witness testimony from hearings conducted by the most recent committee to address the state of prostitution, the Subcommittee on Solicitation Laws, is also reproduced and analyzed. Using the opposing perspectives of victim and rights discourse as a loose framework, particular analytical focus is placed on the language used and ideological beliefs expressed within both the formal reports and testimony. Finally, the core conflicts revealed in Canada's hearings and formal reports on prostitution are placed within a larger body of theory on human agency and the physical body for the purpose of emphasizing the unequivocal necessity of respecting sex workers' autonomy, first and foremost, in any future determination of sex work's place within the social and legal fabric of the country.

\section{Signs and Signification in the Language of Canada's Prostitution Laws}

The debate on prostitution marks its theoretical and political ground, in part, linguistically. ${ }^{4}$ The use of the term 'sex work' by advocates and self-identified sex workers marks a conscious effort to frame the sale of sexual services as work, so its participants may be recognized as deserving of the rights and protections afforded workers in all other industries. The language

\footnotetext{
${ }^{4}$ Shah.
} 
used in discussing prostitution, whether such discussions are taking place in social, legal, academic or government setting, is especially important given the frequency with which meanings ascribed to the verb of prostitution are also uniformly applied to the noun of the sex worker. While individuals are likely to agree that the qualities of an activity do not automatically reflect the qualities of its participant(s), popular opinion tends to collapse the definition of sex worker into the definition of prostitution, defining sex workers' identities en mass solely on the basis of their profession. ${ }^{5}$ In a discourse so deeply embedded with negative gender meanings, even those interested in achieving greater rights and autonomy for sex workers risk appropriating language "predestined to contribute to the marginalization or stigmatization of women-whoprostitute". 6

A look at changes in the language used to define and describe prostitution and its participants in Canada's Criminal Code reflects this struggle to separate the individual from the act; despite frequent condemnation, the act of selling sexual services is, and has always been, legal in Canada, leaving government officials with the challenge of criminalizing the most negative aspects of prostitution without infringing on the rights of Canadian citizens to engage in legal behaviour - a challenge which the Canadian government has repeatedly failed to achieve, albeit to varying degrees over time. Though Canada's first prostitution-related offense aimed, ostensibly, to prevent social ills created by visible street prostitution, its description within the Criminal Code located the criminal offense not in the act of street prostitution, but in the very identities of its purveyors; entered into law in 1892, the provision deemed every woman a vagrant who: "being a common prostitute or nightwalker is found in a public place and does not,

\footnotetext{
${ }^{5}$ Pheterson.

${ }^{6}$ Lorraine Nencel, Ethnography and Prostitution in Peru (Sterling: Pluto Press, 2001) 4.
} 
when required, give a good account of herself'. ${ }^{7}$ Remaining essentially unchanged until 1972, this provision required women to prove their virtue; failure to do so meant they were wayward, capricious, and a tramp. To be charged under this offense, a woman did not need to be caught performing, or even offering sexual services in public; her immoral criminality was written on her body, in the way she dressed, looked and moved.

Following a report by the Royal Commission on the Status of Women in 1972 criticizing the provision's inherent gender bias - only female prostitutes, and not their customers (or male prostitutes, for that matter) were criminalized under the vagrancy offense - the country's Criminal Code was re-phrased to focus on the act of solicitation, though the definition of 'prostitute' remained gendered until a further amendment in 1983. The new offense, s.195.1, still proved problematic for women who believed their personal identity remained separate from their line of work; no specific definition was provided for the term 'solicits', giving law enforcement officials the ability to arrest sex workers who merely indicated, through words, action or even appearance, a willingness to engage in prostitution.

Beyond inscribing signs of immorality and sexual perversion upon sex workers' bodies, Canada's Criminal Code provisions relating to prostitution have underscored the persistent belief that one cannot consent to selling a sexual service - at least not without damaging some inherent part of the self, making a person lesser than their peers. Perhaps indicative of "the almost pathological status that sex workers occupy in public discourses on sexual commerce", Canada's laws against prostitution, and the debates they have inspired, often focus unnecessarily on sex workers' identities - their childhood experiences, their past relationship history, their

\footnotetext{
${ }^{7}$ An Act to amend the Criminal Code, 1892, S.C. 1893, c. 32.

${ }^{8}$ Shah 809.
} 
personal habits, etc - as a way of determining why prostitution exists, as though solving sex workers' perceived personal problems would 'save' them from choosing sex work, and eradicate the offensive industry entirely. This fixation on the 'why' of prostitution is troubling for sex workers and their advocates, who continue to urge the Canadian government to set priorities and agendas based on 'how' the sale of sex operates on a daily basis - in particular the increased risk of violence and health issues resulting from the country's criminalization of both indoor and outdoor venues. Under Canadian law, the notion that a woman cannot consent to the sale of sex is self-fulfilling; though the act of consenting is not indicted within the Criminal Code, existing provisions essentially make it illegal to contract sexual services in any conceivable environment, including outdoor locations, cars, and commercial and residential buildings.

\section{A Legislative History}

In the thirty-seven years since the implementation of the solicitation laws, four different formal reports have been released by committees commissioned by the Canadian government and charged with assessing aspects of the country's prostitution laws for the purpose of ongoing law reform: the Fraser Report in 1985, the Department of Justice synthesis report in 1989, the Federal-Provincial-Territorial Working Group's report in 1998 and the Subcommittee on Solicitation Law's report in 2006 . While the release of these reports has encouraged some debate within the House of Commons as to the effectiveness of our Criminal Code in reducing the public harm associated with prostitution, the subsequent changes made to the code have not reflected the majority of the recommendations made by bodies like the Fraser Committee and the

\footnotetext{
${ }^{9}$ Deborah R. Brock, Making Work, Making Trouble: Prostitution as a Social Problem (Toronto: University of Toronto Press, 1998).
} 
Subcommittee on Solicitation Laws, particularly those recommendations advocating regulation measures in place of criminalization.

Proponents of decriminalization of prostitution argue that some relaxation of Canadian law is necessary in order to "infuse the sex worker's consent with greater meaning"10 beyond the abstract form in which it currently exists. Often advocating a hybrid system of decriminalization and regulation, prostitution activists primarily focus on realistic reforms that address the current workplace dangers, and give sex workers greater agency over their bodies - not just in terms of what they can do, but also where they can safely offer sexual services, and who they want to contract with. The repeal, or at least modification of, some of Canada's prostitution-related offenses, activists argue, would result in safer workplaces and a wider selection of potential clients, allowing sex workers to be more discerning.

Despite the rational connection between the benefits offered by decriminalization measures and the dangers faced daily by sex workers under the current regime there remains an impediment to change, rooted in the language and construction of commercial sex and its purveyors; recurring with regularity in the various reports and studies commissioned by federal government, the question of human agency over the physical body, especially the female body, and its relation to identity remains so controversial that there is often little common ground between sex work supporters and abolitionists, beyond an agreement to continue debate.

In spite of the lack of consensus over some of the most basic elements of prostitution like the nature of consent, the four long-term research studies have produced considerable qualitative and quantitative research. The vast majority of this research, in particular the quantitative studies

\footnotetext{
${ }^{10}$ Vasey 12.
} 
examining numbers of street sex workers in Canadian cities, reveal a gap between the goals of the prostitution-related offenses present in the Criminal Code and what these provisions actually achieve. Nevertheless, Canada's legal approach to sex work remains unchanged. The federal government's ongoing dismissal of the research and recommendations of their own committees is reflective of Canada's ongoing ideological approach to prostitution as a social problem of cyclical victimization - a characterization that has drawn continual criticism from community and law reform organizations as well as academics in the areas of social science, law and public policy. Examined in detail, these reports appear almost repetitive in their observations, though their conclusions seem to vary depending on the political affiliation of the given committee's members.

\section{The Fraser Report}

Established by the Minister of Justice in June of 1983, the Fraser Committee was given two years to carry out a program of sociological research that would provide the basis for a report that would "consider alternatives...[document] findings and recommend solutions to the problems associated with pornography and prostitution in Canada"." In addition to the legal research conducted by the committee, several different research studies were commissioned and published by the Department of Justice to augment the Fraser Committee's eventual report (see Appendix A). At the same time, a separate group entitled the Badgley Committee was commissioned for the purposes of examining the issue of sexual offenses against children.

\footnotetext{
${ }^{11}$ Special Committee on Pornography and Prostitution (Fraser Committee), Pornography and Prostitution in Canada, vol. 2 (Ottawa: Ministry of Supply and Services Canada, 1985) 6.
} 
Once completed, the Fraser Report totaled 753 pages and included 105 separate recommendations. Interested in providing a framework for their findings, the committee outlined three philosophical approaches to the issue of prostitution at the beginning of their report: conservative, liberal, and feminist. Though the committee did not reject outright the conservative framework, the subsequent findings frequently referenced the key principles of 'individual liberty' and the 'appreciation of sexuality'. 12 Praised by one theorist as taking "a courageous stand"13 against a Conservative regime of repressive intolerance, the Fraser Report recommended penalizing "only the most severe nuisance aspects of street soliciting" and suggested prostitutes should be allowed to operate out of their own residences, either alone or in pairs ${ }^{14}$.

In an anthology of articles written in response to the publication of the Badgley and Fraser Reports, Fraser Committee member John McLaren shares several insights into the committee's approach to the analysis of the country's prostitution law. Describing the social climate in Canada as containing "very real disagreement about whether the protection of individual freedom or an emphasis upon moral or social values should take precedence", ${ }^{15}$ McLaren asserts that despite differences in political and philosophical opinion, members of the Fraser group were unanimously committed to developing a set of recommendations that would "recognize the socio-political and cultural realities in which we operate as a society". ${ }^{16}$ For the Fraser Committee members, this commitment meant a rejection of the country's current prostitution law

\footnotetext{
${ }^{12}$ Fraser Committee 25.

"Michael Kanter, "Prohibit or Regulate? The Fraser Report and New Approaches to Pornography and Prostitution," Osgoode Hall Law Journal 23 (1985): 179.

${ }^{14}$ Fraser Committee 530.

${ }^{15}$ John McLaren, "The Fraser Committee: The Politics and Process of a Special Committee," Regulating Sex: An Anthology of Commentaries on the Badgley and Fraser Reports, eds. John Lowman et al. (Vancouver; Simon Fraser University Press, 1986) 40.

${ }^{16}$ McLaren 45.
} 
as "thoroughly repressive legislation" 17 based on fear rather than provable fact, representative of what McLaren sees as the Canadian public's apparent inability to treat prostitutes as anything other than the "flotsam and jetsam of the community". 18

There is little doubt that the Fraser Committee must have found this attitude of dismissal reflected in the time restrictions and financial limitations placed on them by the federal government, which prevented the Report from including input from the most important participants in the sex industry - the prostitutes themselves. As a result, the Report had large gaps in its findings and recommendations with respect to the less visible forms of off-street prostitution, including escort agencies, massage parlours, and those sex workers operating out of hotels or private residences. ${ }^{19}$ It is perhaps a testament to the obvious ineffectuality of the country's Criminal Code provisions that, even without the ability to incorporate the opinions and experiences of sex workers into their research, the Fraser Committee produced a report highlighting several philosophical as well as practical objections to using the criminal law "to penalize or protect adults who engage voluntarily in commercialized sex". ${ }^{20}$ However, despite the best efforts of the committee to treat sex workers as citizens deserving of legislation which respects their innate rights and addresses their visible needs, the government's haste in demanding a published report was ultimately only the first in a series of actions which belied their disinterest in the real experiences and needs of sex workers.

While the formal response to the Badgley and Fraser Reports issued by the federal government discussed many new and ongoing provisions related to child protection from abuse

\footnotetext{
${ }^{17}$ McLaren 43.

${ }^{18}$ McLaren 47.

${ }^{19}$ McLaren 42.

${ }^{20}$ McLaren 49.
} 
to juvenile prostitution, as well as recommendations for new legislation regulating types of pornography, the government's official response to the recommendations made to decriminalize adult prostitution remained unclear; the Fraser Reports recommendations around decriminalization were neither referenced nor discussed at any point in the twenty-two page report. Viewed by various action groups as indecisive on the issue, the government's response to the Fraser Report seemed to confirm fears that the creation of the committee had been "at best a stalling tactic, and at worst a farce". ${ }^{21}$

Though members of the Fraser Committee and supporters of the sex industry could not have expected the government to immediately adopt much of the report's recommendations without a process of thorough debate within the House of Commons, many were "thoroughly resentful",22 that no effort was made to immediately acknowledge or support the report's attempts at reframing prostitution as "a broader social problem requiring a more comprehensive and integrated socio-legal approach".23 Instead, the government's decision to focus their formal response on the Badgley report and its findings carried with it an unspoken distinction between youth and adult prostitutes which silently pathologized the latter, further legitimizing the repressive measures already in place. Though the Badgley and Fraser Reports were commissioned at approximately the same time, the reprehensible nature of the conduct studied by the Badgley Committee is so universally felt that the sex work examined by the Fraser Committee is almost condemned by association. Worse, the government's obvious prioritizing of the Badgley Report's insights and recommendations supports the common, morally driven narrative of the adult sex worker as evolving from a sexualized and victimized youth. By pairing

\footnotetext{
${ }^{21}$ Mclaren 40.

${ }^{22}$ McLaren 53.

${ }^{23}$ McLaren 51.
} 
issues of sexual abuse and incest with juvenile prostitution, and ignoring the recommendations of the Fraser Report in order to trumpet the necessity of greater criminal provisions to prevent the "personal and social ills"24 created by the 'phenomena' of youth victimization, the federal government communicated a view of adult sex workers as already-broken individuals likely beyond assistance.

In addition to excluding the Fraser Committee's recommendations around regulation and decriminalization from their formal response, the federal government made no effort to introduce legislation altering any prostitution provisions in the initial months following the report's release. As a committee member, John McLaren described the government's response as "limited and disappointing", ${ }^{25}$ while British Columbia theorist and activist John Lowman accused politicians of greeting the report with "a yawning and conspicuous silence". ${ }^{26}$ In light of the various changes to the Criminal Code proposed by the federal government to address the findings of the Badgley Committee, theorist (Name?)M. Kanter suggested that if the Fraser Committee had also "followed the trend toward advocating strengthening the laws...it would almost certainly have resulted in tougher legislation". ${ }^{27}$ Somewhat ironically, the recommendations in the Fraser Report $d o$ contain proposed additions to the country's prostitution laws; the committee advised that a prostitution nuisance offense be created in order to empower the police to deal with the public disturbances commonly attributed to street prostitution. Often described as advocating the complete decriminalization of prostitution in Canada, the Fraser Report's call for the country's

\footnotetext{
${ }^{24}$ Government of Canada, "Guide to the Federal Government's Response to the Reports on Sexual Abuse of Children, Pornography and Prostitution," Regulating Sex: An Anthology of Commentaries on the Badgley and Fraser Reports, eds. John Lowman et. al (Vancouver: Simon Fraser University Press, 1986) 4.

${ }^{25}$ McLaren $\$ 2$.

${ }^{26}$ John Lowman, "Punishing Prostitutes and Their Customers: The Legacy of the Badgley Committee, the Fraser Committee, and Bill C-49," Criminal Justice: Sentencing Issues and Reform, eds. L. Samuelson \& B. Schissel (Saskatoon: Garamond Press, University of Saskatchewan, 1991) 313.

${ }^{27}$ Kanter 172.
} 
Criminal Code provisions to support and protect sex workers was not an attempt to condone the commodification of sex in any absolute sense, but rather to acknowledge prostitution's "prevalence and resilience in a gender and class stratified society". ${ }^{28}$ Unfortunately, the single legislative change eventually brought forth by the federal government in response to the concerns outlined in the Fraser Report only further cemented sex workers' position as marginalized, second-class citizens, alternately ignored and criminalized by so many of their peers.

Bill C-49 \& the Department of Justice's Synthesis Report

A key focus of the recommendations made by the Fraser Committee was the systematic reduction of sex workers operating on the streets; while a drop in street work would eliminate some of the adverse effects prostitution had on residential communities, the Fraser Report's primary concern in targeting street prostitution was to correct the contradictions inherent in Canada's Criminal Code and allow women the ability to work in a comparatively safe and private environment. ${ }^{29}$ Though the Fraser Committee was explicit in their belief that the country needed less repressive legislation in order to improve upon the many problems associated with prostitution, the proposed changes to the Criminal Code introduced in Bill C-49 reflected the government's wholly different ideological position. Replacing S.195(1), the new S.213 law (see Appendix B), dubbed the "communicating law", departed from both the wording and the spirit of the draft provision originally suggested by the Fraser Committee. ${ }^{30}$ Despite the fact that the

\footnotetext{
${ }^{28}$ Kanter 193.

${ }^{29}$ Fraser Committee 547.

30 McLaren 52.
} 
Fraser Report's recommendations represented a cohesive, multi-step approach to addressing the needs of both sex workers and their surrounding communities, S.213 dealt only with street solicitation, representing the very piecemeal approach explicitly rejected by the committee in their report. ${ }^{31}$

Public reception of the new legislation was mixed, as some community organizations championed the introduction of even more restrictive laws prohibiting all public conduct, while sex workers and other prostitutions supporters and advocates saw the law as furthering a paradox in the criminal law which has long promoted "the invisibility of prostitution and of sex workers". ${ }^{32}$ The vaguely defined term 'communicating' within s.213 can effectively apply to any action, word or gesture that a police officer chooses to interpret as being for the purposes of prostitution, essentially giving officers free reign to use the code to 'clean up' streets and push sex workers further out of the public eye, and in turn the public conscience. In addition, the choice to include motor vehicles within the definition of 'public' space further limited the options available to sex worker already prohibited from working indoors.

The negative effects of the new law on sex workers' freedom and safety resulted in a number of cases accusing $\$ .213$ of violating the human rights afforded to sex workers under the country's Charter of Rights and Freedoms. In three appellate cases across the country in $1987,{ }^{33}$ arguments were made that the Criminal Code provisions violated a number of Charter rights including the "rights to freedom of expression, freedom of association, security of the

\footnotetext{
31 McLaren 61.

32 "Not Up to the Challenge of Change: An Analysis of the report of the Subcommittee on Solicitation Laws," Canadian HIV/AIDS Legal Network, 2007, 16 Mar 2009 http://www.aidslaw.ca>.

${ }^{33}$ R. v. Skinner, 79 N.S.R. (2d) 8, 1987; R. v. Jahelka; Reference re ss. 193 and 195.1 (1)(c) of the Criminal Code, (Man.) I S.C.R., 1991
} 
person...presumption of innocence... [and] equality under the law". ${ }^{34}$ Only the Nova Scotia Court of Appeal agreed that S.213 represented an unjustifiable violation of the rights of sex workers, specially their right to freedom of expression. In the majority judgment, Justice MacKeigan made a point of distinguishing the issue of human rights from concerns of morality, asserting that "no matter how much one disapproves of the prostitute...the law must preserve through the Charter their right to live, sexually and otherwise, without interference when no harm is done to anyone else". ${ }^{35}$ When the issue of S.213's constitutionality was finally determined by the Supreme Court of Canada in 1990, however, this distinction was lost; though the court agreed that the section violated sex workers' right to freedom of expression as protected under s.2(b) of the Charter, the explanation provided for its justification under s.1 supported the perception of prostitutes as perpetuating a social evil to the detriment of the general public. Ultimately ruling that the legislative objective of $\mathrm{S.213}$ was only to take prostitution off the streets and out of public view, and that the ill effects of the law on sex workers were justified given the interests of society, ${ }^{36}$ Chief Justice Dickson's judgment affirmed sex workers' identity as marginalized people whose health and safety are of less importance than the public nuisance caused by their behaviour.

In many ways, this characterization of sex workers as inherently less than their peers was unsurprising; while an explicit rendering of sex workers as something less than human with regard to their rights under the law might have been shocking in its directness, the subtle dismissal of sex workers as a problem in need of eradication was in keeping with the ideological stance expressed and promoted by the Canadian government. In light of questions surrounding

\footnotetext{
${ }^{34}$ Challenge of Change 6.

${ }^{35}$ R. v. Skinner, 79 N.S.R. (2d) 8, 1987 at 3.

${ }^{36}$ J.R. Robertson, Prostitution, Current Issue Review 82-2E (Ottawa: Library of Parliament, 2003).
} 
the constitutionality of $S .213$, the federal government was quick to undertake a relatively expansive research project in 1989 that included site studies in five Canadian cities - Vancouver, Calgary, Toronto, Montreal, and Halifax, with smaller studies in Regina, Winnipeg, London, Niagara Falls, Ottawa, Trois-Rivieres, and Quebec City. Interviews were conducted with police officers, Crown attorneys, defense lawyers, judges, prostitutes, customers, pimps, social agencies, and business people and residents in areas affected by prostitution, for the purpose of determining whether $\mathrm{S} .213$ had indeed created "a reduction in the nuisance of street prostitution". ${ }^{37}$ There is no doubt the government hoped the empirical evidence gathered would reveal a sharp decline in the incidence of street work, however the Synthesis Report eventually released in 1990 showed just the opposite; concluding that street prostitution was "as prevalent . as it was before the new law", 38 the report totaled thirty-one pages and contained three new recommendations aimed at providing alternatives for sex workers operating on the street, while further deterring potential customers.

In response to these informed recommendations by the Standing Committee of Justice and the Solicitor General, the government issued a brazen rejection of all three; with regards to the proposal for new social programs to assist sex workers in exiting the industry, they determined that further consultation with prostitutes, agencies and other levels of government was a necessary prerequisite to providing effective services that would meet sex workers' needs. This rejection of the Synthesis Report's recommendations may have been couched in language of concern for the unmet needs of prostitutes, but the government's choice to once again create zero social programs to assist sex workers - despite lengthy research underscoring the need for

\footnotetext{
${ }^{37}$ Department of Justice Canada, Street Prostitution: Assessing the Impact of the Law (Ottawa: Ministry of Supply and Services Canada, 1985).

${ }^{38}$ Department of Justice Canada.
} 
them - cannot be justified. Given that the country made no further move towards discussing the creation of new social programs for prostitutes until the 1998 release of the Federal-ProvincialTerritorial Working Group's report, the government's reasoning seems downright disingenuous and manipulative.

Though almost a decade had passed since the creation of the Fraser Committee, the formal response to the Synthesis Report's reevaluation of Bill C-49 reveals the same ideological position; the government found no fault with laws that "dehumanized the prostitute", ${ }^{39}$ because the grave social ills created by prostitution trump the dangers faced by those working in the industry. Quick to extend legislative measures to assist and protect juvenile prostitutes, the government views youth involved in the sex industry as victims in need of saving. In contrast, the message repeated to adult sex workers is that they must wait for any real supportive measures, until a time when the more important concerns of more important citizens are addressed. The characterization of sex workers as victims in need of saving is clearly problematic. However, it is the federal government's continued dismissal of sex workers as likely beyond saving that appears to have the most ill effects; a social program assisting sex workers to exit the industry might have only helped those truly desperate to leave, but it would have given women an opportunity - reaffirming their right (and their ability) to choose. Instead, the government's decision to appoint a new committee for another lengthy round of research reflects a level of comfort with the status quo of prostitution law in the country, and a bureaucratic prioritizing of policy over public safety.

\footnotetext{
${ }^{39}$ Fraser Committee 525.
} 
The Federal-Provincial-Territorial Working Group

Established less than a year after the government's decision to dismiss the recommendations of the Synthesis Report, the Federal-Provincial-Territorial Working Group was given much the same mandate as its predecessors to "review legislation, policy and practices concerning prostitution related activities". ${ }^{40}$ Much like the Fraser and Badgley Committees, the Working Group contained no current or former sex workers. Instead, membership was comprised of officials from the federal, provincial and territorial jurisdictions. Although further research on complicated social issues is almost always beneficial, the timing of the new initiative calls into question the government's interest in identifying workable solutions; clearly disinterested in the up-to-date findings and opinions of the Standing Committee, their call for more research appears very much like a call for different findings - ones which might support a predetermined decision to leave all provisions intact.

Inexplicably, the Working Group's formal report in 1998 focused very little on the physical and social needs of adult sex workers; the majority of the findings related once again to juvenile prostitution and the harm prostitution creates for communities, with concerns about violence against sex workers discussed only as a secondary topic, included because of its "relation to both issues". At no point in the report were the health and wellbeing of prostitutes addressed. Despite this, the report included significant (if not new, or surprising) findings on the incidence violence against prostitutes. Identifying a relationship between the abuse of prostitutes, including assaults and homicides, and the venue of the sex trade, the Working Group's report

\footnotetext{
${ }^{40}$ Federal-Provincial-Territorial Working Group on Prostitution, Report and Recommendations in respect of Legislation, Policy and Practices Concerning Prostitution-Related Activities (Ottawa: Department of Justice, 1998) Part l(b).

"Federal-Provincial-Territorial Working Group.
} 
noted that "nearly all assaults and murders of prostitutes occur while the prostitute is working on the street". ${ }^{42}$ In response to these findings, the Working Group's major recommendation relating to adult prostitution was for the countrywide implementation of provincial High Risk Homicide Registries, developed in Alberta by the Royal Canadian Mounted Police (first use, or only use?). The goal of this recommendation was not only to assist police in the quick and accurate identification of bodies, but also to encourage sex workers (especially those at a younger age) to "re-examine their involvement in the sex trade". ${ }^{43}$

Though the federal government did not ultimately adopt this suggestion, the very inclusion of such a problematic recommendation is reflective of the morality-based operating ideology of the Working Group itself. The creation of such a registry has social merit for obvious reasons, as fast and accurate identification of murder victims is crucial for grieving families. However, the Working Group's stated desire to use the registry as scare tactic in order to threaten women off the street stands at apparent odds with the previously-commissioned Synthesis Report's rejected recommendation for social programs to assist sex workers in exiting the industry; there is little doubt that a social program designed to assist prostitutes in navigating the emotional and practical ramifications of such a decision would result in a far higher incidence of attrition than a police-operated program reliant on ominous warnings of potentially gruesome death. Nevertheless, the High Risk Homicide Registry was the only exit support for adult sex workers included in the report. Notably, this was not the case for juvenile prostitutes, for whom the Working Group report suggested a variety of social supports aimed at reducing harm and providing exit assistance, including education programs, housing, counseling and training and

\footnotetext{
${ }^{42}$ Federal-Provincial-Territorial Working Group Part 3.

${ }^{43}$ Federal-Provincial-Territorial Working Group Part 3(A)(ii)(a).
} 
employment opportunities. Though the Working Group stops short of actively dismissing adult sex workers as beyond hope, the great disparity in the number of recommendations for assistance sends a very clear message with regards to where (and for whom) the group believed the country's efforts and finances would be best spent.

On the topic of decriminalization and regulation of Canada's sex industry, the Working Group appeared conflicted; tentatively agreeing with the preponderance of evidence indicating some measure of decriminalization would reduce the number of prostitutes forced to operate on the street, they nonetheless rejected the idea of amending the Criminal Code. Instead, the Working Group compared prostitution to gaming and betting, suggesting any possible future 'attempts' at decriminalization should be selective, and under provincial control. ${ }^{44}$ Unsurprisingly, the Working Group bookended all discussion of potential decriminalization measures with insistence that further research be undertaken beforehand, lest Canada "become known for liberalized prostitution laws" or worse, "send a message of endorsement of prostitution". ${ }^{45}$ Perhaps pleased with the Working Group's findings, and wishing the report to speak for itself, the federal government did not issue a formal response after the report's release in 1998. As the first formal committee to affirm the merit of Canada's Criminal Code provisions on prostitution, the group also represented the first formal committee to be comprised solely of political officials. While these two qualities may ultimately be coincidental, the Working Group's official report gave the federal government the 'informed' avocation of the legislation status quo they appeared to desire, and until the 2003 creation of the Subcommittee on Solicitation Laws no further action was taken on the issue of adult prostitution.

\footnotetext{
${ }^{44}$ Federal-Provincial-Territorial Working Group Part 3(B)(iv)(d),

${ }^{45}$ Federal-Provincial-Territorial Working Group Part $3(B)($ iv $)(d)$.
} 


\section{The Challenge for Change}

Following the murder and disappearance of a number of sex workers in Vancouver and Edmonton in 2003, the House of Commons issued a unanimous order for the creation of a Subcommittee on Solicitation Laws to review the current laws "in order to improve the safety of sex-trade workers and communities overall, and to recommend changes that will reduce the exploitation and violence against sex-trade workers". ${ }^{46}$ The Subcommittee was comprised of six members of Parliament, and charged with understanding the ways in which the prostitutionrelated sections of the Criminal Code fail to prevent, or may even contribute to, human rights abuses against sex workers, and identifying ways to address these abuses. ${ }^{47}$ The committee reviewed available literature, and heard testimony from over 300 witnesses including sex workers, academic and legal researchers, policy experts, social service and health workers, police officers, and private citizens before joining together on camera to debate their findings.

While the Subcommittee was able to produce six unanimous recommendations, the formal report released in 2006 revealed a sharp ideological divide; both witnesses and Subcommittee members found themselves adhering to one of two positions - "sex work as victimization" and "sex work as work"48 - identical to the two fields of theoretical discourse on the topic, though the Subcommittee did not reference either theory by name during their hearings or in their final report. Given that the reality of prostitution in Canada likely lies somewhere in between these two opposing views, as truth often does, neither position appears wholly 'wrong' in such a way

\footnotetext{
${ }^{46}$ Standing Committee on Justice and Human Rights, The Challenge of Change: A Study of Canada's Criminal Prostitution Laws (Ottawa: Department of Justice, 2006) 3.

${ }^{47}$ Standing Committee on Justice and Human Rights 3.

${ }^{48}$ Standing Committee on Justice and Human Rights 92.
} 
that would indicate an inability on the part of a witness or Subcommittee member to be persuaded by significant empirical evidence. However, the language used by the Conservative members of the Subcommittee in rendering their minority judgment suggests otherwise, with those members asserting that "the most realistic, compassionate and responsible approach to dealing with prostitution begins by viewing most prostitutes as victims" and declaring prostitution to be "unacceptable in any location". ${ }^{49}$ The Subcommittee Report makes note that members remained unable to bridge the gap between these irreconcilable differences in 'philosophy' throughout the research project, and this disagreement is evident in the discussion of witness testimony; peer-reviewed academic research detailing the relationship between criminalization and the abuse of sex workers' human rights is given the same weight as ideologically based testimony advocating harsher criminal penalties without any accompanying empirical evidence ${ }^{50}$. Where consensus existed between witnesses, the Subcommittee still fell short of collective agreement; though the formal report recognized that "witnesses nearly universally stated that section 213 is not an effective tool for achieving the Subcommittee's mandate relating to the safety of prostitutes and communities", st none of the six unanimous recommendations advocated, or even entertained, the idea of reforming any element of the Criminal Code.

Given the failure of the six members to reach the consensus necessarily to bring about real change (despite their ironic choice of title in their final report), it remains unclear what changes must be made in Canada's approach to the issue of prostitution in order to break the cycle of disagreement and ineffective (or impotent) recommendations which have been the result of every

\footnotetext{
${ }^{49}$ Standing Committee on Justice and Human Rights 90.

${ }^{50}$ Standing Committee on Justice and Human Rights 4.

${ }^{51}$ Standing Committee on Justice and Human Rights 52.
} 
government study on the topic since 1983. With transcripts of nearly every hearing available online, however, there is an opportunity to examine the testimony relied upon by the Subcommitte and identify possible patterns in the issues raised and debated by both witnesses and committee members. The witnesses included in this paper were selected using a convenience sampling method whereby the minutes of every proceeding were examined, witnesses with histories of participation in Canada's prostitution debate were selected, and additional witnesses were chosen at random depending on the need for greater representation in one of four predetermined categories - theorists, the political \& legal system, activists \& advocates, and sex workers. Testimonies were examined in their entirety, and quotations were selected based on the perceived relevancy (or controversial nature, as was the case in some instances) of the statements.

Though the witnesses discussed in this paper represent only a small sampling of those who appeared before the Subcommittee, the vast differences in their opinions of sex work highlight how large a gap remains in the public's opinion on the issue, and several key areas of ideological conflict are apparent. Select quotes from each of the chosen witnesses are reproduced and compared, with particular focus on the language used and ideological beliefs expressed by these individuals during their appearance before the Subcommittee.

\section{The Committee IIearings}

Theorists 
Among the numerous witnesses invited to make short presentations before the Subcommittee, there were several academics from both national and international educational institutions as well as independent researchers with no university affiliation. While many of these presenters had spent a large part of their career studying elements of prostitution, not all of the researchers had conducted their own studies on the topic; nevertheless, most claimed to be experts in their field. Similar to the ideological divide details in the Subcommittee's final report, an examination of the viewpoints shared and language used by these theorists reflects a sharp divide between those who believe in women's right and ability to choose a career in sex work, and those who understand all prostitution to be inherently victimizing and exploitive. Perhaps indicative of the wide variance in the experiences of sex workers within the industry, theorists speaking before the Subcommittee often referenced similar studies and statistics in support of very disparate conclusions.

Arguing that Canada's longstanding prostitution laws "were written in a moral context quite different from our own" ${ }^{\text {, }}$, Dr. John Lowman, professor of Criminology at Simon Fraser University, spoke before the Subcommittee in February of 2005 and urged members to consider both decriminalization and regulation as potential solution to the ineffective status quo. Disbelieving the benefits of criminalization advocated by other, Lowman was also critical of the country's response to the 1985 Fraser Report, Lowman asserted that "the huge mistake made ... was to just take the street prostitution law and reform it. What that said was that we were more concerned about public propriety and property values than we were about prostitutes". After nearly 40 years researching the issue, Dr. Lowman's views on sex work appear rooted in a belief in women's autonomy; declaring the question of choice to be "the most important issue...to

\footnotetext{
52 John Lowman, Testimony before the Subcommittee on Solicitation Laws, Hearing 009, Parliament Building Centre Block, Ottawa, 21 February 2005.
} 
conceptualize when it comes to prostitution", he offered the following observations to the Subcommittee, gathered during the course of his research on the subject:

I meet women with degrees. I meet women who have put themselves through school and then gone on to do whatever, to do some entirely different kind of profession. In other words, I meet people who do have choices.

This experience was echoed by another researcher, Dr. Frances Shaver (Sociology \& Anthropology, Concordia University), whose own qualitative studies revealed that "sex workers [in Canada] have varied work experiences outside the industry, and in fact move about quite a bit within the industry", leaving her to conclude that many sex workers "are not trapped on the street" ${ }^{93}$. Concerned with dispelling common stereotypes about sex workers for the Subcommittee, Dr. Shaver focused her presentation on refuting claims that sex workers all share certain experiences or personal characteristics as a result of their job. For Shaver, sex work is "much more complex than it is typically represented to be", with significant diversity of backgrounds and working conditions. To account for the large gap between her findings and those of other researchers advocating the abolition of prostitution, Dr. Shaver underscored the scope of her research:

We've gone out into the field and done rigorous sampling, not only on the street, where l've done a lot of my research; we've also used appropriate sampling techniques for those who are escorts, those who are dancers, and those who are involved in other parts of the industry. What happens when you do that kind of research is that you capture some sex workers who are in crisis, but the majority of sex workers you capture are those who are not in crisis. They have not come to the attention of the social service agencies. They often aren't coming to the attention, on a regular basis, of the police or the courts.

\footnotetext{
${ }^{5 J}$ Frances Shaver, Testimony before the Subcommittee on Solicitation Laws, Hearing 005, Parliament Building Centre Block, Ottawa, 7 February 2005.
} 
Despite the findings of researchers like Dr. Lowman and Dr. Shaver, other 'experts' who made presentations before the Subcommittee were steadfast in their disavowal of sex workers' agency - a position that was often coupled with very specific notions of human sexuality, and in turn the female body. A professor of Sociology \& Anthropology at the University of Ottawa, Dr. Richard Poulin spoke before the Subcommittee in Montreal and offered his own opinions on the nature of sex work. Stressing that it is "prostitution itself that is violent, not its conditions", Dr. Poulin dismissed the issue of agency entirely, calling it "irrelevant to distinguish between forced prostitution and voluntary prostitution" ${ }^{54}$. Though his disinterest in the concept of sex worker agency is certainly based in large part on his belief that all sex work is violent, and therefore beyond the choices available to any human being, Dr. Poulin's conceptualization of prostitution also reflects an apparent displeasure with aspects of modern sexuality:

In my book ... I talk about the pornographization of the social imagination. Do you know how many pornographic films can be seen on television on the regular and specialty channels? There are messages in pornography. Young people's attitudes have changed with regard to sexuality. There's a different vision of sexuality that also affects the bodies of young people: tattoos, body piercing, etc.

Given his belief in the violent and exploitative nature of some of the sexual habits of today's 'young people', it is little surprise that Dr. Poulin extends this opinion to sex work, regardless of the adult age and consenting attitude of so many participants. Far from advocating a legal prohibition of prostitution, Dr. Poulin urged the Subcommittee to address the problems of prostitution by "focusing on customers and making people aware that it's not right to buy sexual services, to buy the body and sex of another person, [and] by engaging in education".

\footnotetext{
${ }^{54}$ Richard Poulin.
} 
The characterization of sex work as the literal sale of one's body appears common among those who support the abolition of the industry. Dr. Melissa Farley, a clinical psychologist and researcher for the non-profit organization Prostitution Research \& Education, has been widely criticized by sex worker advocates and fellow researchers for using flawed research methodologies and making sweeping generalizations about sex workers. In her presentation to the Subcommittee, Dr. Farley made many controversial statements; declaring that the "very definition of [prostitution] is sexual harassment", she stressed the impossibility of prostitution ever being "a job that's safe for women"ss. Similar to Dr. Poulin's outright dismissal of sex workers" potential agency, Dr. Farley describes prostitution as an activity wherein "the conditions that make genuine consent possible are absent ... it's not a choice the way we ordinarily think of a choice as being made from a range of options".

As "an intrinsically traumatizing and humiliating act and profession", Dr. Farley's image of prostitution not only voids any notion of consent on the part of its female participants, but also permanently damages sex workers' own sexuality. Though she provided no specific statistics to the Subcommittee, Dr. Farley indicated her work as a psychologist had shown her the "massive destruction of autonomous, joyous, free sexuality with [a sex worker's] chosen partner" caused by participation in prostitution. While other theorists like Dr. Lowman and Dr. Shaver do not connect sexuality to the physical body, Dr. Farley's comments to the Subcommittee suggest she views them as inseparable. Describing prostitution as "an institution where one person has the social and economic power to transform another person into the living embodiment of a masturbation fantasy", Dr Farley argued that a relaxation of Canada's prostitution laws, particularly any kind of decriminalization or regulation, would turn the female body into "just

\footnotetext{
${ }^{55}$ Melissa Farley, Testimony before the Subcommittee on Solicitation Laws, Hearing 018, Coast Plaza Hotel \& Suites, Vancouver, 30 March 2005.
} 
another...commodity, like toothpaste or popcorn". This understanding of sexuality and the physical body is at odds with opinions like that of Dr. Lowman, who questioned the right of any government to "tell [a] person they cannot use their body to sell sexual services, they cannot use their body in that way".

Though none of the theorists who spoke before the Subcommittee had personal experience in sex work, most presented their findings and theories on prostitution as fact. This was especially true of so-called abolitionists like Dr. Poulin and Dr. Farley, who refused to acknowledge any instance of positive, consensual sex work. The majority of researchers had conducted studies wherein they spoke with current and former sex workers in different locations across Canada or even internationally. However, the degree to which these researchers listened to the experiences of their subjects is unclear; while Dr. Lowman and others acknowledged the variety of experiences amongst sex workers - both positive and negative - and reinforced the importance of talking to the people who are going to be the subject of legislation, others like Dr. Farley appear to have only heard the experiences that fit with their own opinion of sex workers as universal victims.

\section{The Political \& Legal System}

As the Subcommittee travelled to different cities across the country, they also interviewed fellow politicians at several levels of government, as well as lawyers, legal groups, and members of the federal Department of Justice. Perhaps the most informed about Canadian prostitution, ex-Fraser Committee member and namesake Paul Fraser was also interviewed, with

his testimony extending over an entire afternoon's hearing. Eager to share the history of 
Canada's prostitution laws with the politicians comprising the Subcommittee, Fraser spoke about the influences behind the creation and ongoing enforcement of the country's prostitution provisions; in his observation, there were "dual elements, in the thinking of lawmakers, of the prostitute as both a moral and legal outcast and the need to somehow protect respectable women from the wiles of perverse males [which had] continued to influence the law and its enforcement through the 20 th century"s. In describing the opinion of his committee at the end of their twoyear research study, Fraser gave the following comment:

The view we had, to put it bluntly, proceeded from the proposition that if any person, male or female ... for whatever reason has to or chooses to earn a living in prostitution, then the fruits of that labour should belong to them in this very difficult and cathartic existence.

Despite this understanding of sex work as work, albeit difficult work, Fraser felt the committee's recommendations, in hindsight, fell short of addressing the real needs of sex workers, deeming the final suggestions too paternalistic, too maternalistic, too much concerned with government involvement and strategies that would translate into infrastructure". When asked to speak to his own beliefs about prostitution, Fraser expressed the view that sex work "should be able to find its own level, its own market, and its own form of expression". Though he had not conducted research into the issue in several years, Fraser's comments indicate a conceptualization of women as capable of making their own choices concerning their participation in the sale of sexual services.

This positive view of sex workers' agency did not prevent Fraser, however, from occasionally referring to sex workers in terms that belie any such autonomy; when addressing the issue of pimps, and their exploitive treatment of some sex workers, he described prostitutes'

\footnotetext{
56 Paul Fraser, Testimony before the Subcommittee on Solicitation Laws, Hearing 004, Parliament Building West Block, Ottawa, 2 February 2005.
} 
male pimps as "those who shepherd them" - a comment very similar to abolitionists' construction of sex workers as weak and in need of caring intervention. In addition, though his testimony makes clear he views sex workers as equal members of Canadian society, a comment made in response to a question about reasonable regulatory approaches to prostitution indicates a willingness to place responsibility upon the sex worker herself to prove that equality to others; sharing his support for a licensing scheme wherein sex workers must liaison with a neighbourhood before beginning indoor work in their community, Fraser approved of a system that would "enforce people to come and make the case that they can be good neighbours and that it's going to be beneficial".

Even though some comments made by Paul Fraser seem to conflict with his approval of women's right to choose sex work as a viable job, his characterization of sex workers still affords them more agency than the observations of others who came before the Subcommittee. Appearing to conflate his opinions of sex work with his conception of its participants, Harry Lazarenko, a city councilor for Winnipeg, assured the Subcommittee that "prostitutes are not born to be prostitutes ... there has to be an element that starts them off in that direction"\$7. This conflation is again evident in his later comments on the future of sex work; proclaiming that "as long as there's a sex drive for a male, you will never curb prostitution", Lazarenko appears to position men as the sole determinant of sex work's, and thusly sex workers', very existence. Indeed, female agency factors so little into the city councilor's views on prostitution, that his description of sex work's permanent place in society make the profession into an inanimate object; for Lazarenko, sex work "is there, and it's being used, one way or another".

\footnotetext{
${ }^{57}$ Harry Lazarenko, Testimony before the Subcommittee on Solicitation Laws, Hearing 020, Delta Hotel, Winnipeg, 1 April 2005.
} 
Where sex workers are not described in terms that deny their agency, other individuals from the political and legal sphere appear to buy into some of the most offensive traditional stereotypes of sex workers. Agreeing with RCMP officer Kevin Vickers' description of sex workers as leading "a risky lifestyle" as dangerous, if not downright animalistic, individuals; given that "from the time they are tumed out until they retire, [sex workers] are victims of sexual assault, extortion, robbery, and violence 59 , Morrissey finds it logically intuitive that sex workers in turn become criminals themselves:

The vast majority of women in our federal jail system for serious and often violent crimes have prostitution involvement in their history. If they are willing to endure all of the [elements of prostitution], why would they not also be willing to rob and stab?

Perhaps even worse than his descriptions of sex workers' purported criminal nature is Detective Morrissey's response to the Subcommittee's interest in the official number of sex workers working within his city; as explanation for his inability to give an exact number, Morrissey explains that sex workers are "difficult to count. They are like bears in the woods, they don't hold still'. Though Detective Morrissey's characterization of sex workers has likely been shaped by his own interactions with Edmonton's street population, where he may indeed have encountered some sex worker's with criminal records, his description of sex workers as universally animal-like seem to reflect a belief that the stereotype of prostitutes as wanton, dirty and sex-crazed is quite truthful.

\footnotetext{
${ }^{58}$ Kevin Vickers, Testimony before the Subcommittee on Solicitation Laws, Hearing 024, Parliament Building Centre Block, Ottawa, 13 April 2005.

$59 \mathrm{Jim}$ Morrissey, Testimony before the Subcommittee on Solicitation Laws, Hearing 019, Fairmont Hotel MacDonald, Edmonton, 31 March 2005.
} 
Detective Morrissey is not alone in this opinion; Peter Goldring, Minister of Parliament for Edmonton East, shared with the Subcommittee his desire for increased criminal measure involving the "fingerprinting the prostitutes so that we could control them ... [and prevent] disease-spreading" from city to city, we know who we're dealing with and the police can control things a lot better". While the ideological views of Morrissey, Goldring and others are offensive to anyone who believes sex workers are citizens deserving of support, rather than problems require prohibitive control, it is the disavowal of these women's ability and right to participate in the decisionmaking process regarding Canada's laws that is most troubling. Detective Morrissey no doubt voiced the opinions of many others when he gave the Subcommittee his opinion of the viability of a regulatory regime for sex work in the country:

Most [sex workers] have children. Most have a huge stockpile of health issues and violent criminal records. How are we going to legalize prostitution for people with that background? It's pretty hard to make them fit into an administration.

To describe a regulatory regime - one that might allow women stuck on the street to move indoors and create a safer location to engage in sex work - as something women would have to be pushed into suggests Morrissey may also believe there is truth in one of the most damaging stereotypes of sex workers - that they are cannot be assisted.

It is perhaps the opinions of individuals like Detective Morrissey and MP Peter Goldring that Glenn Betteridge, the Senior Policy Analyst for the Canadian HIV/AIDS Legal Network was referring to when he gave the following statement to the Subcommittee:

\footnotetext{
${ }^{60}$ Peter Goldring, Testimony before the Subcommittee on Solicitation Laws, Hearing 019, Fairmont Hotel MacDonald, Edmonton, 31 March 2005.
} 
[We must be] wary of opinions that are not based on reliable, verifiable evidence or lived experience. Not all opinions are worthy of the same consideration in matters that relate to the health and human rights of groups of people who have been historically marginalized. Perspectives informed by prejudice, stereotypical or dogmatic beliefs, paternalistic, moralistic, or demeaning attitudes, should likewise be eschewed. ${ }^{61}$

This insistence on grounding decisions about the future of sex work legislation in the experiences and opinions of the women who live with the results was echoed by others who appeared before the Subcommittee, like Pam Rubin, Research Coordinator for the Women's Innovative Justice Initiative, who warned members that policies and legislation "not directly grounded in the experience of the women experiencing the violence or in the experience of the front-line workers supporting them will be less effective [and] will have unintended negative consequences for women"62.

Key to the inclusion of sex workers in the debate on prostitution, it seems, is the confirmation of their status as equal members of their community. Catherine Latimer, the Acting Assistant Deputy Minister for the Criminal Law Policy and Community Justice Branch of the federal Department of Justice, explained to the Subcommittee that "when you bring people together to talk about it, the sex trade workers don't exactly have the same power base as some of the others who are concerned about the implications for their neighbourhood"63. In her speech to the Subcommittee Latimer also made an effort to distinguish between adult and youth sex workers - a distinction is crucial in order to affirm adult sex workers' autonomy:

\footnotetext{
${ }^{61}$ Glenn Betteridge, Testimony before the Subcommittee on Solicitation Laws, Hearing 012, Hilton Hotel, Toronto, 15 March 2005.

${ }^{62}$ Pam Rubin, Testimony before the Subcommittee on Solicitation Laws, Hearing 014, Casino Nova Scotia Hotel, Halifax, 17 March 2005.

${ }^{63}$ Catherine Latimer, Testimony before the Subcommittee on Solicitation Laws, Hearing 003, Parliament Building Centre Block, Ottawa, 31 January 2005.
} 
As you talk about adults it becomes less clear whether all those participating in the sex trade should be considered exploited or whether there is a capability of making a rational determination that this is what you want, that among your various options, this is your best one and you're going for it. ${ }^{64}$

Along with emphasizing the agency of sex workers, some who spoke with the Subcommittee emphasized women's autonomy over their own bodies. Believing "the exchange of compensation should not affect the right of an adult to engaged in consensual sex", Katrina Pacey, Director of Pivot Legal Services, called it "an affront to the personal autonomy of sex workers to deny them [that] right ${ }^{965}$. Garth Barriere, a lawyer and contributor to Canada's Pink Triangle Press, echoed this sentiment, telling the Subcommittee that policing consensual sex "causes much more harm than it could ever claim to prevent" $"$. Recognizing women's ability to utilize their body in this way, Pacey told members, helps "distinguish between the notion that they're selling their bodies to anyone ... They're selling sexual services, and that why it's very similar to what maybe a police officer does or someone who is a registered massage therapist, in providing physical services". This construction of prostitution as work, equal to other professions, matches the ideology of rights discourse, which frames sex work as a career that women ought to have the legal ability to choose.

As participants in the debate on prostitution, members of the political and legal sphere such as lawyers, politicians, police officers and legal advocates have a direct hand in the creation and enforcement of the country's laws on sex work. While consultations with experts and concerned citizens often occur before the implementation or amendment of legislation, it is only those within this sphere who get a 'vote'.

\footnotetext{
${ }^{64}$ Catherine Latimer.

${ }^{65}$ Katrina Pacey.

${ }^{66}$ Garth Barriere, Testimony before the Subcommittee on Solicitation Laws, Hearing 018, Coast Plaza Hotel, Vancouver, 30 March 2005.
} 


\section{Activists \& Advocates}

During the months of public hearings held by the Subcommittee, representatives of many community, activist and advocate groups were invited to speak about their experiences with prostitution. Depending on the day and location of a particular hearing, advocates of sex workers' rights often presented alongside community groups calling for further criminalization and religious or political groups emphasizing the dangerous immorality of the sex industry. Though participants were instructed to speak directly to the Subcommittee, tension between participants over the issue of morality was commonplace. Jennifer Clamen, a member of the Coalition for the Rights of Sex Workers, addressed this tension directly, urging the Subcommittee to acknowledge the "serious disconnect between sex workers' experiences and the interpretation of sex work from the outside" ${ }^{67}$. This disconnect, according to Clamen, was the result of a variety of social influences:

These are realistic and understandable misconceptions, given the way sex work is portrayed in the media, pop culture, and in our opinions in everyday conversations. ... Sometimes this entails viewing sex work as a morality issue; other times it involves constructing sex work as a negative manifestation of women's sexual exploitation, poverty, or individual pathology.

Clamen's views were shared by other sex work advocates including former sex worker Cynthia Low, a member of the Sex Workers Action Network, who suggested the concept of 'immorality' is different for everyone:

\footnotetext{
${ }^{67}$ Jennifer Clamen, Testimony before the Subcommittee on Solicitation Laws, Hearing 013, Hyatt Regency Hotel, Montreal, 16 March 2005.
} 
I think the word "immoral" always comes up in discussions here, and I think we all have a line around it. I think stockbrokers are immoral. I think the environmental degradation that goes on and is legitimatized is immoral. And some would say that some politicians are immoral. So we all have our way of looking at that ${ }^{68}$.

Though both Clamen and Low suggested a view of sex work as uniformly immoral missed the nuances created by individual experience, neither described the beliefs of anti-prostitution activists as 'wrong'. Rather, both encouraged the Subcommittee and other presenters to consider the value of individual opinions.

The respect for personal beliefs shown by Clamen and Low was not often echoed in the presentations made by members of anti-prostitution groups, particularly those rooted in conservative or religious ideals. Generally emphasizing the evils of prostitution rather than the prostitutes themselves, many participants nonetheless framed sex work as unequivocally wrong. Peter Veeenendaal, a research coordinator for Reformed Perspective Foundation (a charity-based organization promoting the participation of conservative religions' participation in politics), made perhaps the most alarming analogy of the 'wrongs' of prostitution, calling sex work "an activity of exploitation, not unlike the one my parents witnessed in the Netherlands in the 1940s. ... the Nazis used the Jewish people for their own purposes, and if they resisted they were murdered"69.

While Veenendaal was the only participant to use such a dark analogy, many other participants likened the concept of legal sex work to a moral vacuum. Though they appeared at different hearings in different cities, Janice Raymond (Co-executive Director, Coalition Against

\footnotetext{
${ }^{68}$ Cynthia Low, Testimony before the Subcommittee on Solicitation Laws, Hearing 017, Coast Plaza Hotel, Vancouver, 29 March 2005.

${ }^{69}$ Peter Veenendaal, Testimony before the Subcommittee on Solicitation Laws, Hearing 020, Delta Hotel, Winnipeg, 1 April 2005.
} 
Trafficking in Women) and Hermina Dykxhoome (Alberta Federation of Women United for Families) gave extremely similar accounts of the dangers created by legalization; while Raymond warned the Subcommittee that "when legal barriers disappear, so too do the social and the moral and the ethical barriers" ${ }^{90}$, Hermina gave a slightly more succinct warning, reminding members that "when legal barriers disappear, so do social and ethical barriers"'. Though the sentiment expressed by both women is a fairly common opinion of those opposing the legalization or regulation of sex work, the nearly matching language used by Raymond and Dykxhoome gives them the appearance of parroting a party line rather than expressing their own experience-based beliefs.

One group of activists whose presentations were almost uniformly rooted in personal experience, perhaps to a fault, were the representatives of neighbourhood watch groups created in cities across the country in order to address the effects of local street-based sex work. While discussions about sex work often frame prostitutes as victims, Cristina Basualdo (Vice-President, Alberta Avenue Neighbourhood Patrol) described her own neighbours as "a community of victims deprived of their liberty and security"72. Whether or not Basualdo meant for the Subcommittee to focus on the victimization of communities in addition to, or in the place of, concerns for the victimization of sex workers is unclear from her presentation. However, other participants were more direct in their statements; admitting to having "no learning about what the situation is for the street prostitutes", Shelly Severson (an Edmonton citizen) dismissed the lives of sex workers as "not [her] concern right now" though she agreed that "it should be, as a good

\footnotetext{
${ }^{70}$ Janice Raymond, Testimony before the Subcommittee on Solicitation Laws, Hearing 021, Parliament Building Centre Block, Ottawa, 4 April 2005.

${ }^{71}$ Hermina Dykxhoome, Testimony before the Subcommittee on Solicitation Laws, Hearing 019, Fairmont Hotel MacDonald, Edmonton, 31 March 2005.

${ }^{72}$ Cristina Basualdo, Testimony before the Subcommittee on Solicitation Laws, Hearing 019, Fairmont Hotel MacDonald, Edmonton, 31 March 2005.
} 
citizen"73. Shannon Ross Watson, a volunteer at the John School in Edmonton (formed as an alternative to the criminal prosecution of those charged with soliciting), also appeared to dismiss the experiences of sex workers, informing the Subcommittee that, rather than the health risks and physical harm faced by many sex workers, the "most insidious effect of street prostitution is the perception or reality that [her] neighbourhood is now unsafe"74.

As participants in the debate on sex work, these individuals represent citizens whose experience with sex work is often uniformly negative, given the close proximity between visible sex work and their family homes. It is not these participants' concerns for their communities that is problematic, but instead the way they place the needs of sex workers far below the needs of themselves and their neighbours. In a sort of backhanded acknowledgement of sex workers' agency, many community activists appeared to feel that sex workers' choice of prostitution as a profession negated their right to ask for assistance with some of the consequences of their work; Shannon Ross Watson, theoretically more educated about sex work than other citizens as a result of her work with the John School, told the Subcommittee that "street prostitutes are not getting killed because of our laws; it is because they are doing something risky and dangerous". Though an emphasis on the real choices available to many women performing sex work is generally a positive advancement over traditional victim discourse, community activists' often vehement stance against the decriminalization of prostitution often seemed to position the rights and concerns of sex workers as 'lesser than' the concerns of communities where street sex occurs.

\footnotetext{
${ }^{73}$ Shelly Severson, Testimony before the Subcommittee on Solicitation Laws, Hearing 019, Fairmont Hotel MacDonald, Edmonton, 31 March 2005.

${ }^{74}$ Shannon Ross Watson, Testimony before the Subcommittee on Solicitation Laws, Hearing 019 , Fairmont Hotel MacDonald, Edmonton, 31 March 2005.
} 
The perception of sex workers as less than equal within Canadian society was identified by some participants as a key roadblock to any real revision of the country's prostitution laws. Cheryl Hotchkiss, a representative of Amnesty International, emphasized the need for a separation of women's professions from their personal identity:

The attitudes of the general public, police, and courts toward women working in the sex trade suggest that they see these women of less value or importance than other members of society. Regardless of what a woman is doing to earn an income, she must be provided with adequate protection from experiencing grave human rights violations, which may ultimately result in her death ${ }^{75}$.

Where sex workers are not treated as equal citizens, some participants argued that prostitutes face mistreatment from the very individuals supposed to protect them - law enforcement. Describing the relationship between sex workers and police officers in her own city of Vancouver, Jennifer Clamen informed the Subcommittee that "women who did report to the police were ignored, were told they were lying, or were told that being beaten up and raped was part of their job...prevent[ing] any sort of recourse on behalf of the sex worker". Beyond a mistrust or dismissal of sex workers' experiences, others identified the barrier between sex workers and other Canadian citizens as supplying an excuse for "some members of our community to justify their inability to work toward an inclusive city for everyone who lives and works there, not just those who own homes and businesses"”6

Many of the statements made by the anti-prostitution activists appearing before the Subcommittee not only echoed elements of victim discourse, but also embodied the attitude of inequality described by sex worker advocates. Often these statements were made in response to

\footnotetext{
${ }^{75}$ Cheryl Hotchkiss, Testimony before the Subcommittee on Solicitation Laws, Hearing 024, Parliament Building Centre Block, Ottawa, 11 April 2005.

${ }^{76}$ Cynthia Low.
} 
questions about exit programs for women interested in leaving prostitution - programs which are very popular with activists who view all sex work as immoral and dangerous. Describing these women as persons needing to "regain a sense of dignity, self-esteem, and purpose in their lives"77, Gwendolyn Landolt (National Vice-President, REAL Women of Canada ${ }^{78}$ ) was less positive when speaking about sex workers looking to remain within the industry; offered as explanation for why exit programs are often underused by women employed in sex work, Landolt informed the Subcommittee that "these women cannot help themselves. They're too drugged out, they're alcoholic, and they couldn't keep a doctor's appointment if they wanted to". The confluence of sex work with addiction was repeated by Cristina Basualdo, who suggested that "prostitution, crime, and drug addiction never occur in isolation from one another". While each of these participants purported to be supportive of prostitutes and interested in their wellbeing, their statements make clear that 'wellbeing', in their minds, has a very finite definition and does not include participation in any form of sex work. Women with positive opinions about their participation in the industry are, in turn, described by these activists as helplessly deluded individuals with bad habits. Shawna Hohendorff, a program coordinator with Kindred House, likened participation in sex work to other common 'vices', telling the Subcommittee that sex workers' exits from the industry are often delayed because "people slowly change behaviours, as we all slowly change behaviours. ... all of us have dieted or stopped smoking or have broken habits. ... I'm not as organized as l'd like to be"79. Janice Raymond, in her appearance before the Subcommittee, devoted part of her statement to refuting

\footnotetext{
${ }^{77}$ Gwendolyn Landolt, Testimony before the Subcommittee on Solicitation Laws, Hearing 007, Parliament Building Centre Block, Ottawa, 14 February 2005.

${ }^{78} \mathrm{REAL}$. Women of Canada, a national non-profit organization promoting Conservation 'family' values, made a motion in April, 2009 to join the current constitutional challenge of Canada's prostitution laws as a 'friend of the court' intervenor. This motion was rejected on July 2,2009 and is pending appeal.

${ }^{79}$ Shawna Hohendorff, Testimony before the Subcommittee on Solicitation Laws, Hearing 019, Fairmont Hotel MacDonald, Edmonton, 31 March 2005.
} 
the claims of sex workers who purport to have had positive experiences in the industry, warning Subcommittee members that when sex worker advocates are "appearing before a committee or the media, in many instances they're not going to say this is exploitation or this was a terrible experience for me ... [they] want to deny the reality of their own lives".

Key to the 'reality' of sex work described by many anti-prostitution activists is the framing of sex as a private expression of love, rather than a consensual physical act. Describing sex work as contributing "to the breakdown of the family, which should be the backbone of a healthy society", Peter Veenendaal warned the Subcommittee that "by distorting human sexuality and commodifying human intimacy--both ordained by God for marriage between a man and a woman ... [prostitution turns] acts of love and sexual intimacy ... into commercial transactions". This sentiment was shared by Reverend Harry Lehotsky, Director of the New Life Ministries, who also warned the Subcommittee of the impropriety of sex work, explaining that "to penetrate people repeatedly in every imaginable orifice is not a right thing by many different people. It's not a healthy thing"so. While every individual is entitled to their own beliefs about something as personal as sexuality, it is the universal scope of the statements made by some antiprostitution activists that infringes upon the rights of others, including sex workers, to participate in or support the sex industry. Not only are sex work advocates and participants positioned as incorrect or even deluded, they are also described as abnormal and perverted; in an attempt to detail the ills of prostitution, Hermina Dykxhoome described customers as "men who...usually, or probably, want something beyond the physical act that we normally think of as normal. ... who need to be exposed, or ... [given] some consequence".

\footnotetext{
${ }^{80}$ Harry Lehotsky, Testimony before the Subcommittee on Solicitation Laws, Hearing 020, Delta Hotel, Winnipeg, 1 April 2005.
} 
This projection of perverted, criminal character onto all customers in the sex industry is again problematic primarily because of the universal scope of the characterization. Given the opportunity to provide her opinion about the john schools in her area of British Columbia, Jennifer Clamen expressed concern that negative characterizations of johns is often accompanied by the framing of sex workers as helpless victims:

[There is a] kind of brainwashing a lot of the men who want to have sex with sex workers have to go through. They're taught that women are weak. They're taught that women don't have any independence or autonomy. They're taught that women are just used as sexual objects and that they shouldn't take part in this system anymore, and that's why they're being punished, because they did that. I don't think that's the kind of thing we need to be promoting either.

The stigmatization of commercialized sex was cited by others as inhibiting progress in addressing the real ills of prostitution. Suggesting Canadians "lose all context when we're talking about something that falls under "old-fashioned vice"", Michael Vonn (Policy Director of the BC Civil Liberties Association) urged the Subcommittee to be mindful of the "other [Criminal Code] provisions by which, if you were a sex trade worker, you could get a response to your complaint that you were being threatened, that you were being assaulted, that somebody is exploiting you"\$1. As former sex workers, both Cynthia Low and Jennifer Clamen were also troubled by the effects of stigmatization on the reformation of prostitution law within the country, suggesting that if communities were "a little more open about the purchase of sex as a practice ... there would be more opportunities to talk about legislation, like the construction industry, like real

\footnotetext{
${ }^{81}$ Michael Vonn, Testimony before the Subcommittee on Solicitation Laws, Hearing 018, Coast Plaza Hotel \& Suites, Vancouver, 30 March 2005.
} 
estate, like any other kind of economic machine" ${ }^{\star 82}$, and questioning the practical merit of the Subcommittee"s "consultation with ideologies of different kinds"

Where other participants in the debate on prostitution addressed the issue of future law reform, those who favoured the beliefs of victim discourse were unequivocally against any form of regulation and decriminalization. Such a position is historically popular and, again, not problematic for its conclusions but rather the reasoning offered to the Subcommittee; frequently, anti-prostitution activists descriptions of the process needed to address the issue of prostitution excluded input from sex workers themselves, who were deemed "naîve and negligent"s4 individuals who "don't really know the answers to all of those questions that we [the activists] seem to know around the table"ss. Presented with the prospect of regulation or some form of decriminalization, many anti-prostitution activists' reactions presupposed the impossibility of any workable type of law reform. despite the successful use of such regimes in different countries worldwide. Asserting that "the law cannot protect people whose activities pose a risk to their own safety and well-being if it puts their rights ahead of those of the victims of their activities", Cristina Basualdo appeared unable to envision a scenario where the health and safety of both sex workers and other citizens could be protected, despite the fact that legal regimes allowing only indoor prostitution have been successful in both regards ${ }^{\text {so }}$. In response to a question about the construction of sex work as work (as in rights discourse), Peter Veenendaal

\footnotetext{
Q. Gindia Low:

s* Jennifer Clamen.

Harry Lehoisky.

\$s Shawna Hohendortf.

Nohn Lownan. "Submission to the Subcomnittee on Solicitation Laws of the Standing Comminee on Justice, Human Rights. Public Safery and Emergency Preparalness" $2005<$ hrtp: mupase.unisene.ca" $-10 u m a n>3$

Fetruary 2009.
} 
provided the Subcommittee with hypothetical worst-case scenarios that were exceedingly farfetched:

Does that mean we will list prostitution in our career choices books at our schools? Does that mean my wife or my daughter is in danger of losing her employment insurance benefits if she refuses to take such a job? Will the newest hooker-training academy be opened along the road my kids take to school?

Where participants were given the opportunity to put forth viable changes to the Criminal Code, anti-prostitution activists often based their suggestions on a view of the law as "a guideline for behaviour" ${ }^{\$ 7}$. Favouring increased criminalization of prostitution, Cristina Basualdo suggested that adding penalties to the current section 213 (the "communicating" law) would "help prostitutes by allowing faster identification and a quicker investigation of their murders.... [and] act as a deterrent to those not already entrenched in the trade, decreasing the risk to them". Though Basualdo's goal of eradicating prostitution appears to include decreasing the risks faced by sex workers, increased criminal penalties seems an incongruous solution to the health and safety concerns experienced by prostitutes, unless one believes that, primarily, what sex workers need is to learn the unacceptable (and immoral) nature of their behaviour.

An examination of the statements made by each different 'grouping' of participants in the Subcommittee hearings reveals a common ideological gap between those who support sex work in one way or another, and those who condemn prostitution as unequivocally wrong and harmful; however, this gap seems the most evident - and indeed the most daunting - when examining the testimony of various activists and advocates. Though not everyone appearing before the Subcommittee fits easily within a victim discourse/rights discourse dichotomy, the majority of community and social activists and advocates who made presentations use language that closely

\footnotetext{
${ }^{87}$ Gwendolyn Landolt.
} 
matches the ideology of one 'side', whether or not the individuals have any awareness of these terms or theories. The extreme discrepancy present in the various legal reforms promoted by these representatives is alarming, and yet it is the differing characterization of sex work and sex workers, in particular with regards to morality and agency, that seems the most problematic - in no small part because it is also, undoubtedly, the most difficult gap in opinion to ever try and 'bridge'. For victim discourse proponents in particular, there often appears a kind of refusal to even consider the experiences and observations of the 'other side', even when that other side includes the only individuals with hands-on, personal experience with sex work.

\section{Current \& Former Sex Workers}

Though comparatively fewer sex workers appeared to speak before the Subcommittee than nearly any other representative 'group', these women (and they were all women, despite the presence of male sex workers throughout the country) are without a doubt the most relevant and potentially educational participants to share their opinions and experiences with the Subcommittee. By far the least divided population to appear at the hearings, sex workers who gave statements about their experiences in sex work tended to emphasize many of the same points raised by rights discourse, particularly the perceived loss of their autonomy through the language used by so many to discuss sex work. Scarlett Lake, a prior sex worker and current madam, shared her insights with the Subcommittee after more than twenty-five years in the industry:

My experience in the sex trade is very healthy and positive. I've had a very comfortable living. I've met very nice people, and I consider myself as somebody who looks after the ladies who work for me in a responsible manner and hopefully give them an alternative in 
terms of being able to work in the sex trade without being victimized in any way, shape, or form ${ }^{88}$.

While Lake's opinion alone is not indicative of every sex worker's experience, other sex workers urged the Subcommittee to understand the difference between advocating for choice in sex work, and claiming that prostitution is always positive. Cherry Kingsley, a current sex worker, explained that she and other advocates are not "in denial about health, safety, addictions, violence. We're actually saying that those conditions are very real for women today--for many, many women. We're not in denial'"89.

Critical of those who would make sweeping statements about the nature of prostitution, some sex workers emphasized the danger of making universal assumptions; Kara Gillies, a sex worker and Chairperson for Maggie's: The Toronto Prostitutes' Community Service Centre, compared assumptions about the victimization of sex workers to assumptions about domestic abuse:

It must be noted that the preponderance of violence against women occurs in the home at the hands of a personal partner. We don't, however, jump to the conclusion that violence is therefore inherent in marriage or in dating, nor do we presume to combat the problem by criminalizing marriage or dating activities ${ }^{90}$.

Asked to address the relationship between criminalization and the social stigma faced by sex workers, she pointed to the invasive nature of the procuring laws in particular, under which "both personal and professional relationships are subject to state scrutiny and serious negative

\footnotetext{
${ }^{88}$ Scarlett Lake, Testimony before the Subcommittee on Solicitation Laws, Hearing 018, Coast Plaza Hotel \& Suites, Vancouver, 30 March 2005.

${ }^{89}$ Cherry Kingsley, Testimony before the Subcommittee on Solicitation Laws, Hearing 007, Parliament Building Centre Block, Ottawa, 14 February 2005.

${ }^{9}$ Kara Gillies, Testimony before the Subcommittee on Solicitation Laws, Hearing 027, Parliament Building Centre Block, Ottawa, 2 May 2005.
} 
sanction". However, Gillies made clear she did not feel that the criminalization of prostitution within Canada had created the stigma she faced:

Criminalization does not cause social stigma; however. it reflects and then reinforces stigma. When the state criminalizes so many aspects of our lives, the work and relationships, it sends a very clear message that we are somehow aberrant and not worthy of respect. That does directly lead to abuse and harassment.

Where participants insisted criminalization has harmed sex workers, however, is in attaching a criminal history to any sex worker caught $\&$ convicted of attempting to perform what remains a legal activity; Cherry Kingsley warned the Subcommittee that criminal records "define women with that experience, whether it was their choice or not their choice, completely, whether they were a child or an adult. Because they are considered to be criminals, it's defined how they're able to access basic services even".

In addition speaking about the emphasizing the variety of sex worker experiences within the industry, many participants took issue with the use of the word 'victim' to describe prostitutes. Lauren Casey, a sex worker and member of Prostitutes' Empowerment Education and Resource Society, urged the Subcommittee to "realize and recognize that there are people who do quite well and are quite willing to work and want to work"", while Anastasia Kusyk, a sex worker and member of the Sex Workers' Alliance of Toronto, rejected the notion that anyone else could determine her degree of victimization: "I'm very upset by hearing this word "victim". I choose to decide whether I have been victimized, and I am victimized by stigma. I am victimized by politics ${ }^{292}$. Cherry Kingsley also emphasized her right and ability to make personal choices,

\footnotetext{
${ }^{91}$ Lauren Casey, Testimony before the Subcommittee on Solicitation Laws, Hearing 017, Coast Plaza Hotel, Vancouver, 29 March 2005.

${ }^{92}$ Anastasia Kusyk, Testimony before the Subcommittee on Solicitation Laws, Hearing 012, Hilton Hotel, Toronto, 15 March 2005.
} 
and linked the use of the term 'victim' to the historical exclusion of prostitutes from political debate on the issue:

I really wish people would stop representing us that way. It's part of what has perpetuated our not having the right to speak for ourselves or to communicate on our own behalf. It's perpetuated this stigma, this shame, this stereotype, and our lack of ability to participate as community members--we aren't able to communicate, we aren't able to make decisions for ourselves, people literally have to intervene, and we just shouldn't even speak, really.

Recognizing the generally well-meaning motives of many of the individuals who describe and treat sex workers as victims, Kingsley urged individuals to recognize the role their own efforts at 'assistance' may play in sex workers' struggles: you have to understand there is people's violence, there are people's morality issues, there is people's targeted discrimination, and there is people's helpfulness, all of which have contributed to a climate of intolerable conditions".

A crucial element of many sex worker' construction of prostitution as real work is the characterization of commercial sex as natural and beneficial. Defining sex work as "a valuable service, one that is heartening and enlightening and advances people's well-being in a very holistic manner", Kara Gillies was critical of efforts on the part of some anti-prostitution advocates the construe the sale of sex as inherently negative and without value:

I think it sends a very disturbing and negative, indeed sex-negative, message to say that purchasing sexual services is inherently negative and undermines our communities and our well-being; whereas, in reality, sex is central to and pertinent to who we are as humans, and not everybody is able to access that in a non-commercial manner.

In an effort to give the Subcommittee a greater understanding of the emotional and psychological complexities that can exist within commercial sex, Anastasia Kusyk gave an example of her own experiences in the industry: 
I don't believe every guy who purchases the services or the sexual services of a prostitute is pathological, is a sex addict. I've had many of my clients say to me.... One guy just blurted out, "My wife lost both her breasts to breast cancer." Is this something gentlemen can talk to one another about? No. So a lot of times when they come to see sex workers, the sex is actually secondary. In some regards, you're performing a psychiatric or a psychological service, believe it or not.

The characterization of sex as not only work, but beneficial work, appeared to be shared by every sex worker whose testimony was examined, despite how deeply this description contradicts the beliefs of other researchers, politicians, police officers and activists purporting to hold expert knowledge in the realities of prostitution. Many sex workers acknowledged the gap between others' perspectives and their own experience, and urged the Subcommittee to incorporate greater consultation with sex workers into their own research. Suggesting that the government cannot "change attitudes and stigma overnight unless ... people of prominence [are] ... stepping forward and saying, "listen, these women are workers and they have a right not to die in their work", Anastasia Kusyk's statement reflects the incredibly high stakes faced by many sex workers in the country, particularly those forced to work on the street. Though respect for their autonomy and the merit of sex work would be helpful, the need for a true understanding of the realities of sex work, stripped of questions of morality and discomfort with sexuality, is rooted in health risks and physical danger. As Criminal Code sanctions continue to "undermine [sex workers'] security ....and agency ${ }^{403}$, the greatest need on the part of sex workers seems to be the right to an equal voice:

I just wish people would also hear what we're saying, just as we hear those people you're debating. W'e're not sitting here on drugs representing ourselves. And we can make appointments; we're here today. We made our appointment to come here and we're able to drive. We're able to speak ${ }^{\text {a4 }}$.

\footnotetext{
${ }^{93}$ Kara Gilles.

${ }^{94}$ Cherry Kingsley.
} 


\section{The Prostitute Personified: A Way Forward}

As evinced by the testimony of many of those who appeared before the Subcommittee, the perceived morality of the services performed a sex worker are often practically inscribed upon the body of the prostitute herself, altering her identity and affecting the degree of autonomy allotted to her by her peers. The concept of the body as signifier has been problematic for many feminist scholars, who note the danger of allowing a society so deeply rooted in patriarchal thought to inscribe meaning upon the female body. ${ }^{95}$ Declaring the body to be "a site where regimes of discourse and power inscribe themselves, a nodal point or nexus for relations of juridical and productive power", Judith Butler suggests "the body has its invariably public dimension" $" 97$ - a dimension which includes "the mark(s) of gender"98, and all of the social expectations which accompany such categorization. For Butler, to be a body "is to be given over to others" classifications that mark a primary and inaugurative alienation in sociality". ${ }^{100}$

While the male body has traditionally been encoded with signs of power and strength, the female body is socialized into performing in a feminine and thusly more constrained manner. Starting at a young age, girls are encouraged to develop bodily habits that reflect the traditional feminine ideal of passive, malleable beauty - habits that become self-enforcing over time; the

\footnotetext{
${ }^{95}$ Sandra L. Bartky. "Foucault, femininity, and the modemization of patriarchal power," Feminism and Foucault: Reflections on Resistance, eds. I. Diamond and L. Quinby (Boston: Northeastem University Press, 1988); S. Budgeon, "Identity as an Enbodied Event," Body \& Society 9.1 (2003): 37-57; E. Grosz, Volatile Bodies: Towards A Comoreal Feminism (Indianapolis: Indiana University Press, 199.4); Iris M. Young, Throwing like a girl and other essays in feminist philosophy and social theory (Bloomington: Indiana University Press, 1990).

Judith Butler, "Foucault and the Paradox of Bodily Inscriptions," The Joumal of Philosophy 86.11 (1990): 601607 at 601.

${ }^{97}$ Judith Butler, "Violence, Mouming, Politics," Studies in Gender and Sexuality 4 (2003): 9-37 at 26

os Judith Butler, Gender Trouble (New York: Routledge, 1990) 8.

99 Judith Butler, Undoing Gender (New York: Routledge, 2004) 20.

${ }^{100}$ Judith Butler, The Psychic Life of Power (Stanford: Stanford University Press, 1997) 28.
} 
more a girl assumes her status as feminine, the more she "takes herself to be fragile and immobile and the more she actively enacts her own body inhibition". ${ }^{101}$ As women internalize the panoptical gaze of the male connoisseur, they learn to live their bodies as "seen by another, by an anonymous patriarchal Other" ${ }^{102}$ Consequently, including the physical body in feminist analyses of identity and agency has been a problematic issue in recent scholarship, born out of a fear of reinforcing the association of 'female' with 'body'. ${ }^{103}$

Whether or not theorists challenge the socially imposed and self-disciplining 'signs' of the female body, struggle for control over the body remains at the centre of women's lived experience. ${ }^{104}$ At the core of this struggle is women's ability to remain sovereign over a body that is "an object of (hetero)sexual desire in a patriarchal culture". ${ }^{105}$ If a woman's sexuality is encoded in and performed by her body, then society dictates her sexuality is not only heteronormative but also focused on male pleasure. As a result, intimate physical encounters are perilous, for "if women are seen to be doing them outside a narrowly circumscribed set of contexts (namely with one man, in private and as an expression of desire) then they risk imputations of disreputability and immorality". ${ }^{106}$ Indeed, female sexuality is never solely about sex, or the sexual, but rather "a tableau upon which different scripts can be written. ... discourses such as: morality and immorality, good and bad, disease and health, dirt and cleanliness,

\footnotetext{
101 Young 154.

102 Bartky 72.

${ }^{103}$ A. Witz, "Whose Body Matters?: Feminist Sociology and the Corporeal Turn in Sociology and Feminism," Body \& Society 6.2 (2000): 1-24.

${ }^{104}$ J. Arthurs and J. Grimshaw, "Introduction," Women's Bodies: Discipline and Transgression, eds. J. Arthurs and J. Grimshaw (London: Cassell, 1999); S. Bordo, Unbearable Weight: Feminism, Western Culture and the Body (Berkeley: University of California Press, 1993); K. Davis, "Introduction," Embodied Practices: Feminist Perspectives on the Body, ed. K. Davis (London: Sage, 1997) 1-23.

${ }^{105}$ J. Wesely, "Growing Up Sexualised: Issues of Power and Violence in the Lives of Exotic Dancers," Violence Against Women 8.10 (2002): 1182-207 at 1182.

${ }^{106}$ Sara Oerton and Joanna Phoenix, "Sex/Bodywork: Discourses and Practices," Sexualities 4.4 (2001): 387-412 at 389.
} 
reputability and disreputability". ${ }^{107}$ This imposition actively reduces the autonomy afforded to women, and limits the choices available to them in shaping their own personal identities; unable to ever wholly 'be themselves', women must also wear the qualities and imputations assigned to them by others' assessments of their sexual expression.

The question of whether "identity is inseparable from the sexual construction of the self"108 has particular relevance to the discourses surrounding female prostitution. While the meanings ascribed to the sexual act have always been socially and culturally determined, affected by place and history ${ }^{109}$, the decision to perform sexual acts in return for compensation has long been regarded as immoral and against nature. In his Lectures on Ethics, Immanuel Kant defines the physical body as inseparable from one's identity; to allow a person access to one's body for profit is therefore "to dispose over oneself as over a thing and to make of oneself a thing on which another satisfies his appetite, just as he satisfies his hunger upon a steak". ${ }^{10}$ This perception is echoed by some contemporary scholars, as well as many of the witnesses included in the paper, who believe sex to be in all cases "an intimate expression of one's sexuality, which is inseparable from one's self"'", and argue that a woman cannot ever consent to such a use of her body, as to do so would result in a fundamental devaluing or even destruction of identity.

Despite the fact that many of the most vocal abolitionists have no personal experience with sex work $^{112}$, the ideology shared by the vast majority of these individuals - victim discourse -

\footnotetext{
${ }^{107}$ Oerton and Phoenix 391.

${ }^{108}$ Carole Pateman, The sexual contract (Cambridge: Polity, 1988) 207.

${ }^{10}$ Michel Foucault, The History of Sexuality Vol. 2: The Use of Pleasure (London: Penguin, 1992).

${ }^{110}$ Immanuel Kant, Lectures on Ethics, Trans. Louis Infield (Indianapolis: Hackett, 1963) 165-166.

"II Adanı Vasey, "Sex Work and Consent," Diss. York University, 2003 at 8.

112 Melissa Farley, "Prostitution: The oldest use and abuse of women;" Off Our Backs May 1994; Alexis Kennedy et. al, "Child Maltreatment; Routes of Recruitment: Pimps' Techniques and Other Circumstances That Lead to
} 
presupposes that sex work is universally and inherently violent. ${ }^{113}$ Research studies undertaken by proponents of this view (including Subcommittee witnesses Janice Raymond and Melissa Farley) often focus primarily on issues of youth prostitution and international human trafticking, as well as rates of drug use and childhood abuse among sex workers. ${ }^{114}$ As subsections of the prostitute population most vulnerable to exploitation, the subjects of such studies embody the notion that "real choice to engage in prostitution is impossible" representative of any universal reality of prostitution. When personal accounts of current and former sex workers contradict the concept of the "exploited woman', proponents of victim discourse often dismiss such opinions as misguided, desperate self-denial:

Women who are compromised, cajoled, pressured, tricked, blackmailed, or outright forced into sex ... often respond to the unspeakable humiliation ... by claiming that sexuality as their own. Faced with no alternative, the strategy to acquire self-respect and pride is: I chose it. $^{116}$

Critics of victim discourse argue that the binary construction of agency and victimization as mutually exclusive categories leaves sex workers with "no subjective space in which to articulate the relevance of consent to their daily lives". ${ }^{117}$ Though supporters of the views of victim discourse purport to protect women from harm, some argue that their efforts carry with them the message that sex workers cannot 'save' themselves. Worse, sex workers who resist such descriptions and claim agency over their bodies and choices are presented as damaged,

Street Prostitution," Journal of Aggression, Maltreatment \& Trauma 15.2 (2007); Mary Lucille Sullivan, Making Sex Work: A Failed Experiment with legalized Prostitution (Melbourne: Spinifex Press, 2007).

${ }^{113}$ Vasey 106.

${ }^{114}$ Ronald Weitzer, "Flawed Theory and Method in Studies of Prostitution," Violence Against Women 11.7 (2005): 934-949.

${ }^{115}$ Svati P. Shah, "Prostitution, Sex Work and Violence: Discursive and Political Contexts for Five Texts on Paid Sex, 1987-2001," Gender \& History 16.3 (2004): 794-812 at 808.

${ }^{115}$ Catherine Mackinnon, Toward a Feminist Theory of the State (Cambridge: Harvard University Press, 1989) 149150.

117 Vasey 84. 
dangerous and over-sexed products of their corrupt environment ${ }^{118}$ whose wanton, reckless behavinur perpetuates a cycle of abuse for all women. Just as many sex workers are patronized and silenced as "having an inherent lack of agency - as coerced slaves and victims of "false consciousness", others are "castigated for having an excess of agency, as irresponsibly trafficking in male fantasies and commodification". ${ }^{119}$

Though it can be considered "a radical political stance to assume prostitute legitimacy" many proponents of rights discourse argue it is not the nature of prostitution itself but rather "the legal apparatuses of the state [which serve] as the central source of ... repressive power that subjugates prostitutes". ${ }^{21}$ This viewed was shared by many of the current and former sex workers who appeared before Canada's Subcommittee, who spoke of the increased danger and lack of autonomy they experienced as a result of the criminalization of their chosen work. Integral to the goals of rights discourse is a separation of sex from personal identity; if the sex act can be "stripped of ... [its] presumed unique relationship to nature and the self, it no longer automatically follows that [its] alienation or commodification is simply and necessarily destructive". ${ }^{122}$ The construction of commercial sex as work within rights discourse does not imply the absence of emotion; rather, supporters emphasize women's ability summon and contain emotion and intimacy, by choice, within the temporary bounds of a commercial transaction without experiencing a loss of self. ${ }^{123}$

While the services performed by sex workers are indisputably "related in a more intimate

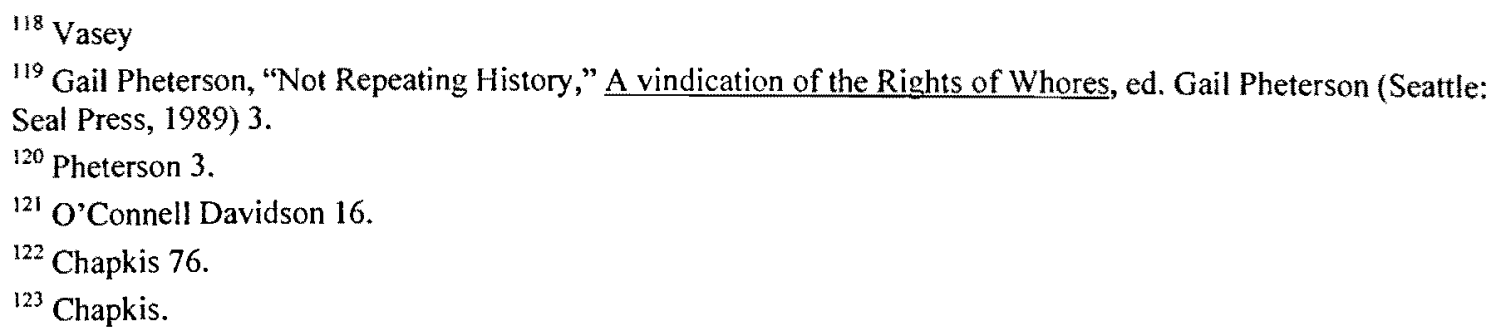


manner to her body than those of other professionals":24, the construction of sex work as work within rights discourse simultaneously constructs the human body as the private property of an individual - a vessel to claim as one's own and use as one sees fit, without stigma. ${ }^{125}$ Proponents of rights discourse argue that efforts on the part of sex workers to reclaim ownership of their own bodies and distance themselves from imputations of immorality often result in further stigmatization, as these 'victims" are relabeled 'whores' and their bodies are "publicly reinscribed as disreputable, dirty, illicit and sexy."126 Rights discourse advocates for a construction of the female body in "terms that may grant women the capacity for independence and autonomy, which thus far have been attributed only to men" "27, and attempts to combat the social conflation of the meanings of sex, sexuality and identity by displacing these hegemonic inscriptions on the female body through the production of new meanings. ${ }^{128}$

Unable to reconcile the victim/agent dichotomy at the heart of prostitution discourse, sex workers, advocates and theorists alike find themselves at sociopolitical loggerheads ${ }^{129}-$ conflict which ultimately only perpetuates the ongoing stigmatization of sex workers. Even sex workers themselves do not speak with a univocal voice ${ }^{130}$; despite its notorious role as the "world"s oldest profession', there remains no single, authoritative narrative of prostitution, and no available space for the sex worker beyond the margins of social consciousness. This reality is plainly evident not only in Canada's history of prostitution legislation, but also the outcome of the

\footnotetext{
124 Pateman 562 .

${ }^{125}$ Anne McClintock, "Sex Workers and Sex Work: Introduction," Social Text 0.1 (1993): 7; Mary Mclntosh, "The feminist debate on prostitution," paper presented to BSA Annual Conference, Sexualities in Context. Preston $\mathrm{CK}$, March 1994; Pheterson.

${ }^{126}$ Oerton and Phoenix 404.

${ }^{127}$ Grosz xiii.

${ }^{128}$ Shannon Bell, Readins. Writing, and Rewriting the Prostitute Bodv (Bloomington: Indiana University Press, 1994).

${ }^{129}$ Belinda J. Carpenter, Re-Thinking Prostitution: Feminism, Sex, and the Self (New York: Peter Lang, 2000).

${ }^{130}$ McClintock.
} 
country's most recent debate on the topic; despite the numerous hearings held across the country and the hundreds of Canadian citizens consulted for the Subcommittee's formal report, the federal government released no official response to the report's publication. Nevertheless, the Subcommittee's unwillingness to produce detailed recommendations for specific action on the part of the government did not go unnoticed by supporters of sex workers' rights. The Canadian HIV/AIDS Legal Network in particular criticized the Subcommittee, releasing an eight-page critique of the formal report to the public. Calling the Subcommittee's mandate "nothing less than a matter of life and death for sex workers", ${ }^{131}$ the Legal Network's response accused members of endorsing the view of sex workers as victims and reducing them "to people who need to be 'protected' by the state, without regard for their right to make their own choices". 132

When viewed collectively, the research and reports on prostitution commissioned by the Canadian government since 1982 constitute several thousand pages of empirical evidence documenting the harm caused by the criminalization of prostitution. The history of prostitution law in Canada appears as a history of failure, hurting both sex workers and their surrounding communities while accomplishing little. Despite the heavy criminal restrictions the government has placed on prostitution, there has been no documented decrease in the number of individuals working in the sex industry - it is only the opportunity for safety measures that has dwindled, as sex workers are forced to take customers to increasingly isolated and dangerous environments in order to avoid police interference. ${ }^{133}$ The hope felt by members of the Fraser Committee and sex workers in the country upon the publication of the first formal report on prostitution in Canada has all but disappeared, as advocates for the rights of prostitutes have seen both empirical

\footnotetext{
${ }^{131}$ Challenge of Change 1.

${ }^{132}$ Challenge of Change 4.

${ }^{133}$ S. O'Connell, "The Impact of Bill C-49 on Street Prostitution: What's Law Got To Do With It?" Joumal of Law and Social Policy 4.109 (1988): 142.
} 
findings and witness testimonies fail to persuade the fideral govemmon of the dingervus marginalization created by their contradictory laws.

After examining prior govemment repurts and duzens of testimonics from participunts in the most recent government study on the topic, the sme contlict of language and idewligy is repeated: regardless of the time and lowation. conversations abut prostitution within Canada follow an almost predictable pattern of spinning wheds and little progress. Though sex worhers and their supporters grow ever more voeal and insistent that their perspective - be it based in the ideals of rights discourse or in a acemulation of personal experione - be acknowledsed by those charged with representing their interests and adjressing their needs on a national scalc, the most problematic element of Canada's debate over the future of sex work is the perpotual marginalization and exclusion of the very citizens whose livelihoods are being discusscu.

By constructing sex workers as victims harmed by their very participation in the industry. many government officials, lawyers, activists and theorists alike are stealing the identity and autonomy of the people they claim to protect. Worse, these helpless women are ignored, dismissed as delusional or high, or accused of lying outright when anyone attempts to contradict the views and values of the more knowledgeable abolitionists. Though nearly crery vocal antiprostitution advocate points to their support of sex workers looking to leave the trade as proof of their care and concern for prostitutes, this desire to help exiting sex workers reintegrate into society' sends a clear message to every woman who choose to stay: you are wrong, you are damaged, you are not like us, stay away. 


\section{Works Cited}

Arthurs, J. and J. Grimshaw. "Introduction." Women's Bodies: Discipline and Transgression. Eds. J. Arthurs and J. Grimshaw. London: Cassell, 1999.

Barriere, Garth. Testimony before the Subcommittee on Solicitation Laws, Hearing 018. Coast Plaza Hotel, Vancouver. 30 March 2005.

Barry, Kathleen. The prostitution of sexuality. New York: New York University Press, 1995.

Bartky, Sandra L. "Foucault, femininity, and the modernization of patriarchal power." Feminism and Foucault: Reflections on Resistance. Eds. I. Diamond and L.

Quinby. Boston: Northeastern University Press, 1988. 61-86.

Basualdo, Cristina. Testimony before the Subcommittee on Solicitation Laws, Hearing 019. Fairmont Hotel MacDonald, Edmonton. 31 March 2005.

Bell, Shannon. Reading, Writing, and Rewriting the Prostitute Body. Bloomington: Indiana University Press, 1994.

Betteridge, Glenn. Testimony before the Subcommittee on Solicitation Laws, Hearing 012. Hilton Hotel, Toronto. 15 March 2005.

Bordo, S. Unbearable Weight: Feminism, Western Culture and the Body. Berkeley: University of California Press, 1993.

Brock, Deborah R. Making Work, Making Trouble: Prostitution as a Social Problem. Toronto: University of Toronto Press, 1998.

Budgeon, S. "Identity as an Embodied Event." Body \& Society 9.1 (2003): 37-57.

Butler, Judith. "Foucault and the Paradox of Bodily Inscriptions." The Journal of Philosophy 86.11 (1990): 601-607.

Butler, Judith. Gender trouble. New York: Routledge, 1990.

Butler, Judith. The Psychic Life of Power. Stanford: Stanford University Press, 1997.

Butler, Judith. "Violence, Mourning, Politics." Studies in Gender and Sexuality 4 (2003): 9-37.

Butler, Judith. Undoing Gender. New York: Routledge, 2004.

Carpenter, Belinda J. Re-Thinking Prostitution: Feminism, Sex, and the Self. New York: Peter Lang, 2000.

Casey, Lauren. Testimony before the Subcommittee on Solicitation Laws, Hearing 017. Coast Plaza Hotel, Vancouver. 29 March 2005. 
Chapkis, Wendy. Live sex acts: Women performing erotic labour. London: Cassell, 1997.

Clamen. Jennifer. Testimony before the Subcommittee on Solicitation Laws, Hearing 013 . Hyatt Regency Hotel, Montreal. 16 March 2005.

Davis, K. "Introduction." Embodied Practices: Feminist Perspectives on the Body. Ed. K. Davis. London: Sage, 1997. 1-23.

Department of Justice Canada. Street Prostitution: Assessing the Impact of the Law. Ottawa: Ministry of Supply and Services Canada, 1985.

Dykxhoome, Hermina. Testimony before the Subcommittee on Solicitation Laws, Hearing 019. Fairmont Hotel MacDonald, Edmonton. 31 March 2005.

Farley, Melissa. "Prostitution: The oldest use and abuse of women." Off Our Backs May 1994.

Farley, Melissa. Testimony before the Subcommittee on Solicitation Laws, Hearing 018. Coast Plaza Hotel \& Suites, Vancouver. 30 March 2005.

Federal-Provincial-Territorial Working Group on Prostitution. Report and Recommendations in respect of Legislation, Policy and Practices Concerning Prostitution-Related Activities. Ottawa: Department of Justice, 1998.

Foucault, Michel. The History of Sexuality Vol. 2: The Use of Pleasure. London: Penguin, 1992).

Fraser, Paul. Testimony before the Subcommittee on Solicitation Laws, Hearing 004. Parliament Building West Block, Ottawa. 2 February 2005.

Gillies, Kara. Testimony before the Subcommittee on Solicitation Laws, Hearing 027. Parliament Building Centre Block, Ottawa. 2 May 2005.

Goldring, Peter. Testimony before the Subcommittee on Solicitation Laws, Hearing 019. Fairmont Hotel MacDonald, Edmonton. 31 March 2005.

Government of Canada. "Guide to the Federal Government's Response to the Reports on Sexual Abuse of Children, Pornography and Prostitution." Regulating Sex: An Anthology of Commentaries on the Badgley and Fraser Reports. Eds. John Lowman et. al. Vancouver: Simon Fraser University Press, 1986. 2-6.

Grosz, E. Volatile Bodies: Towards A Corporeal Feminism. Indianapolis: Indiana University Press, 1994.

Hall, S. et. al. Modernity and its Futures. Cambridge: Polity Press, 1992.

Hohendorff, Shawna. Testimony before the Subcommittee on Solicitation Laws, Hearing 019. Fairmont Hotel MacDonald, Edmonton. 31 March 2005.

Hotchkiss, Cheryl. Testimony before the Subcommittee on Solicitation Laws, Hearing 024. Parliament Building Centre Block, Ottawa. 11 April 2005. 
Jeffreys, Sheila. The idea of prostitution. Melbourne: Spinifex Press, 1997.

Kant, Immanuel. Lectures on Ethics. Trans. Louis Infield. Indianapolis: Hackett, 1963.

Kanter, Michael. "Prohibit or Regulate? The Fraser Report and New Approaches to Pornography and Prostitution." Osgoode Hall Law Journal 23 (1985): 179.

Kennedy, Alexis et. al. "Child Maltreatment; Routes of Recruitment: Pimps' Techniques and Other Circumstances That Lead to Street Prostitution.” Journal of Aggression, Maltreatment \& Trauma 15.2 (2007).

Kingsley, Cherry. Testimony before the Subcommittee on Solicitation Laws, Hearing 007. Parliament Building Centre Block, Ottawa. 14 February 2005.

Kusyk, Anastasia. Testimony before the Subcommittee on Solicitation Laws, Hearing 012. Hilton Hotel, Toronto. 15 March 2005.

Lake, Scarlett. Testimony before the Subcommittee on Solicitation Laws, Hearing 018. Coast Plaza Hotel \& Suites, Vancouver. 30 March 2005.

Landolt, Gwendolyn. Testimony before the Subcommittee on Solicitation Laws, Hearing 007. Parliament Building Centre Block, Ottawa. 14 February 2005.

Latimer, Catherine. Testimony before the Subcommittee on Solicitation Laws, Hearing 003. Parliament Building Centre Block, Ottawa. 31 January 2005.

Lazarenko, Harry. Testimony before the Subcommittee on Solicitation Laws, Hearing 020. Delta Hotel, Winnipeg. 1 April 2005.

Lehotsky, Harry. Testimony before the Subcommittee on Solicitation Laws, Hearing 020. Delta Hotel, Winnipeg. 1 April 2005.

Low, Cynthia. Testimony before the Subcommittee on Solicitation Laws, Hearing 017. Coast Plaza Hotel, Vancouver. 29 March 2005.

Lowman, John. "Punishing Prostitutes and Their Customers: The Legacy of the Badgley Committee, the Fraser Committee, and Bill C-49." Criminal Justice: Sentencing Issues and Reform. Eds. L. Samuelson \& B. Schissel. Saskatoon: Garamond Press, University of Saskatchewan, 1991. 299-318.

Lowman, John. Testimony before the Subcommittee on Solicitation Laws, Hearing 009. Parliament Building Centre Block, Ottawa. 21 February 2005.

Lowman, John. "Submission to the Subcommittee on Solicitation Laws of the Standing Committee on Justice, Human Rights, Public Safety and Emergency Preparedness." 2005 $<$ http://mypage.uniserve.ca/ lowman $>3$ February 2009.

MacKinnon, Catherine. Toward a Feminist Theory of the State. Cambridge: Harvard University Press, 1989.

McClintock, Anne. "Sex Workers and Sex Work: Introduction." Social Text 0.1 (1993): 7. 
Melntosh. Mary: "The feminist debate on prostitution." Paper presented to BSA Annual Conference, Sexualities in Context. Preston LK. March 1994.

MeLaren. John. "The Fraser Committee: The Politics and Process of a Special Committec." Regulating Sex: An Antholosy of Conmentaries on the Badsley and Fraser Remurts. Eds. John Lowman et al. Vancouver: Simon Fraser University Press 1986. $39-46$.

Morrissey, Jim. Testimony before the Subcommittee on Solicitation Laus, Hcaring 019. Fairmont Hotel MacDonald. Edmonton. 31 March 2005.

Nencel. Lortaine. Ethnograghy and Prostitution in Peru. Sterling: Pluto Press, 2001.

"Not Lp to the Challenge of Change: An Analysis of the report of the Subcommittec on Solicitation Laws." Canadian HIV/AIDS Lesal Network. 2007. 16 Mtar 2009 hith: Mum aidslaw.ca>.

O'Connell, S. "The Impact of Bill C 49 on Street Prostitution: What's Law Got To Do With It?" Joumal of Law and Social Policy 4.109 (198s): 139-151.

O'Connell Davidson. Julia. Prostitution. Power and Fredom. Ann Arbor: Lniversing of Michigan Press. 1998.

Oenon. Sarah and Joanna Phoenix. "Sex Bodywork: Discourses and Practices." Sevualitics 4.4 (2001): $387+12$.

Pacey. Katrina. Testimony before the Subcommittee on Solicitation Laws. Hearing 017. Coast Plaza Hotel, Vancouver. 29 March 2005.

Pateman, Carole. The sexual contract. Cambridge: Polity, 19ss.

Pheterson. Gail. "Not Repeating History:" A vindication of the Rights of Whores. Fd. Gail Pheterson. Seattle: Seal Press, 1959.

Poulin, Richard. Testimony hefore the Subcommittee on Solicitation Laws, llearing 006. Parliament Building Centre Block, Ottawa. 9 February 2005.

R. v. Jahelka.

R. v. Skinner. 79 N.S.R. (2d) S. 1987.

Raymond. Janice. Testimony before the Subcommittee on Solicitation Laws. Hearing 021. Parliament Building Centre Block, Ottawa. + April 2005.

Reference re Ss. 193 and 195.1(1)(c) of the Criminal Code. (Mlan.) I S.C.R. 1991.

Robertson, J.R. Prostitution. Current Issue Review 82-2E. Ottawa: Library of Parliament. 2003.

Rubin. Pam. Testimony before the Subcommittee on Solicitation Laws. Hearing 014. Casino Nova Scotia Hotel, Halifax. 17 March 2005. 
Severson, Shelly. Testimony before the Subcommittee on Solicitation Laws, Hearing 019. Fairmont Hotel MacDonald, Edmonton. 31 March 2005.

Shah, Svati P. "Prostitution, Sex Work and Violence: Discursive and Political Contexts for Five Texts on Paid Sex, 1987-2001." Gender \& History 16.3 (2004): 794-812.

Shaver, Frances. Testimony before the Subcommittee on Solicitation Laws, Hearing 005. Parliament Building Centre Block, Ottawa. 7 February 2005.

Special Committee on Pornography and Prostitution (Fraser Committee). Pornography and Prostitution in Canada, vol. 2. Ottawa: Ministry of Supply and Services Canada, 1985.

Standing Committee on Justice and Human Rights. The Challenge of Change: A Study of Canada's Criminal Prostitution Laws. Ottawa: Department of Justice, 2006.

Sullivan, Mary Lucille. Making Sex Work: A Failed Experiment with legalized Prostitution. Melbourne: Spinifex Press, 2007.

Vasey, Adam. "Sex Work and Consent." Diss. York University, 2003.

Veenendaal, Peter. Testimony before the Subcommittee on Solicitation Laws, Hearing 020. Delta Hotel, Winnipeg. 1 April 2005.

Vickers, Kevin. Testimony before the Subcommittee on Solicitation Laws, Hearing 024. Parliament Building Centre Block, Ottawa. 13 April 2005.

Vonn, Michael. Testimony before the Subcommittee on Solicitation Laws, Hearing 018. Coast Plaza Hotel \& Suites, Vancouver. 30 March 2005.

Watson, Shannon Ross. Testimony before the Subcommittee on Solicitation Laws, Hearing 019. Fairmont Hotel MacDonald, Edmonton. 31 March 2005.

Weitzer, Ronald. "Flawed Theory and Method in Studies of Prostitution." Violence Against Women 11.7 (2005): 934-949.

Wesely, J. "Growing Up Sexualised: Issues of Power and Violence in the Lives of Exotic Dancers." Violence Against Women 8.10 (2002): 1182-207.

Witz, A. "Whose Body Matters?: Feminist Sociology and the Corporeal Turn in Sociology and Feminism." Body \& Society 6.2 (2000): 1-24.

Young, Iris M. Throwing like a girl and other essays in feminist philosophy and social theory. Bloomington: Indiana University Press, 1990. 